\title{
Honest Confusion: The Purpose of Compensatory Damages in Tort and Fraudulent Misrepresentation
}

\author{
Jill Wieber Lens*
}

\section{INTRODUCTION}

Suppose that a plaintiff is injured in a rear-end collision car accident. Even though the rear-end collision was not a dramatic accident, the plaintiff incurred extensive medical expenses because of a preexisting medical condition. Through a negligence claim, the plaintiff can recover compensatory damages based on his medical expenses. But is it fair that the defendant should be liable for all of the damages? It is not as if he rear-ended the plaintiff on purpose. Maybe the fact that defendant's conduct was not reprehensible should reduce the amount of damages that the plaintiff recovers.

Any first-year torts student knows that the defendant's argument will not succeed. The defendant's conduct does not control the amount of the plaintiff's compensatory damages. The damages are based on the plaintiff's injury because, in tort law, the purpose of compensatory damages is to make the plaintiff whole by putting him in the same position as if the tort had not occurred. ${ }^{1}$

But there are tort claims where the amount of compensatory damages is not always based on the plaintiff's injury. Suppose that a defendant fraudulently misrepresents that a car for sale is brand-new. The plaintiff then offers to purchase the car for $\$ 10,000$. Had the car actually been new, it would have been worth $\$ 15,000$, but the car was instead worth only $\$ 10,000$. As they have for a very long time, the majority of jurisdictions would award the plaintiff $\$ 5000$ in compensatory damages based on the plaintiff's expected benefit of the bargain. ${ }^{2}$

\footnotetext{
* Assistant Professor, Baylor University School of Law. The author would like to thank Todd Pettys for his valuable comments on earlier drafts of this Article.

1. See infra Part II.B.

2. See infra Part III. "Cases raising questions as to the choice between the "benefit of the bargain' rule and the 'out of pocket' rule have been most common in the situations involving alleged misrepresentations as to value, quality, or condition." Annotation, "Out of Pocket" or "Benefit of
} 
Courts label these damages "compensatory," but do not treat them like compensatory damages. For instance, even if courts adhere to the majority rule, some would award $\$ 0$ in compensatory damages because the defendant did not profit from the sale and the plaintiff has no out-ofpocket losses. ${ }^{3}$ Similarly, the majority of courts would award $\$ 0$ in compensatory damages if the defendant was merely negligent in making the misrepresentation. ${ }^{4}$

Treating benefit-of-the-bargain damages as compensatory has skewed the meaning of compensatory in tort law. If factors other than the plaintiff's injury change the amount of damages, are the damages still compensatory? If so, what does compensatory mean anymore? More importantly, if tort law tolerates undercompensation of parties injured by fraudulent misrepresentation, what's to stop the defendant in a rear-end collision from successfully reducing damages based on his conduct?

Benefit-of-the-bargain damages cannot be compensatory in tort, and none of the practical or theoretical justifications for awarding benefit-ofthe-bargain-based compensatory damages for breach of contract apply to tort law. To restore the meaning of compensatory damages in tort law, courts must limit compensatory damages for fraudulent misrepresentation to the plaintiff's out-of-pocket losses. The purpose of benefit-of-the-bargain damages is, and always has been, to punish the defendant because he committed fraud; these are punitive damages in tort.

Part II of this Article discusses the distinct purposes of compensatory damages in contract and tort law. Part III discusses courts' adoption of benefit-of-the-bargain-based compensatory damages for fraudulent misrepresentation. Part IV explores the difficulty in distinguishing contract and tort actions, a difficulty increased due to the similarity in the damages awarded. Part V argues that benefit-of-the-bargain damages are not compensatory as contemplated by tort law. Part VI further argues that the reasons and justifications for awarding benefit-of-the-bargainbased compensatory damages in contract law do not apply to tort law. The last Parts of the Article explore the consequences of awarding benefit-of-the-bargain-based compensatory damages in tort and conclude that benefit-of-the-bargain damages in tort should be awarded only as punitive damages.

the Bargain" as Proper Rule of Damages for Fraudulent Representations Inducing Contract for the Transfer of Property, 13 A.L.R. 3d 875, 952 (1967). This Article focuses on this most common type of fraudulent misrepresentation.

3. See infra notes $199-203$ and accompanying text.

4. See infra Part V.B. 


\section{THE PURPoSES OF COMPENSATORY DAMAGES IN CONTRACT VERSUS TORT}

A plaintiff can recover compensatory damages in both breach-ofcontract and tort actions. However, the purposes and measures of those compensatory damages differ.

\section{A. Contract}

In contract law, "[t]he purpose[] of awarding contract damages is to compensate the injured party" and not to punish the breaching party. ${ }^{6}$ The traditional approach to measuring compensatory damages is based on fulfilling the nonbreaching party's interests. ${ }^{7}$ The purposes relevant to this Article are the expectation and reliance interests.

\section{Compensatory Damages Based on the Nonbreaching Party's Expectation Interest}

The goal of the expectation interest is to award the nonbreaching party that amount of money "necessary to ensure that the aggrieved party's position after the award will be the same - to the extent money can achieve the identity - as if the other party had performed." ${ }^{8}$ Expectation interest damages put the nonbreaching party in the same place as if the breach had not occurred. ${ }^{9}$ These damages give the nonbreaching party "relief based on the disappointment in his expectation, as measured by the net gain that he would have enjoyed had the promise been performed." ${ }^{10}$ These damages are typically known as

5. RESTATEMENT (SECOND) OF CONTRACTS $\S 355 \mathrm{cmt}$ a (1981).

6. E. Allan Farnsworth, Legal Remedies for Breach of Contract, 70 Colum. L. REV. 1145, 1146 (1970). Liability for breach of contract is "blind to fault" and strict-the breaching party is liable regardless of whether the breach was intentional or innocent. Id. at 1146-47. Not surprisingly, punitive damages are generally not available for breach of contract. But see infra note 263 (explaining that punitive damages are available in a tort action even if the conduct that is the basis of the tort claim also constitutes a breach of contract).

7. Eric G. Andersen, The Restoration Interest and Damages for Breach of Contract, $53 \mathrm{MD}$. L. REV. 1, 9-10 (1994). Regardless of what type of compensatory damages are available - based on either the expectation or the reliance interest-the plaintiff will also be entitled to consequential damages, assuming that they were within the parties' contemplation at the time of entering into the contract. See 1 Dan B. Dobbs, Law of Remedies: Damages-Equity-Restitution § 3.2, at $289, \S 3.4$, at 321 (2d ed. 1993).

8. David H. Vernon, Expectancy Damages for Breach of Contract: A Primer and Critique, 1976 WASH. U. L.Q. 179, 183.

9. Farnsworth, supra note 6, at 1147-48.

10. Id. at 1148 . 
benefit-of-the-bargain damages because they give the nonbreaching party the benefit he expected to receive from the contract he made. ${ }^{11}$ The damages give the nonbreaching party something he did not have before he made the contract. ${ }^{12}$

Benefit-of-the-bargain damages also usually have the effect of placing the breaching party in the same position as if he had performed. ${ }^{13}$ For instance, requiring the breaching party to pay benefit-of-the-bargain damages may mean that the breaching party has to pay damages in the amount that he expected to lose in the bargain. ${ }^{14}$ Thus, in contract law, benefit-of-the-bargain damages usually put both parties in the same economic position as if both parties performed.

\section{Compensatory Damages Based on the Nonbreaching Party's \\ Reliance Interest}

Damages based on the reliance interest, on the other hand, "compensate[] a party for losses or harms that were incurred or suffered based on the assumption that the promise of the breaching party would be kept."15 Reliance interest damages put the nonbreaching party in the same position as before he entered into the contract, ${ }^{16}$ as opposed to the position as if the contract existed but had been breached.

Damages based on the reliance interest cannot exceed damages based on the expectation interest. ${ }^{17}$ Because of this, a plaintiff generally does not seek reliance damages if expectation damages are available. ${ }^{18}$ Most commonly, a plaintiff seeks reliance damages when he is unable to

\footnotetext{
11. Id.

12. Commentators have thus characterized expectancy damages as a "queer kind of 'compensation," but justifiable because the damages encourage people to enter into contracts. Id. (quoting L.L. Fuller \& William R. Perdue Jr., The Reliance Interest in Contract Damages: 1, 46 YALE L.J. 52, 53 (1936)).

13. Vernon, supra note 8, at 191. As discussed by Farnsworth, if "society were seriously concerned with the compulsion of promisors, it might at least be expected to impose civil penalties for the breach of contract if it chose not to impose criminal ones." Farnsworth, supra note 6, at 1146.

14. See Vernon, supra note 8, at 184 .

15. Andersen, supra note 7 , at 9.

16. Vernon, supra note 8, at 247 ("In its pure form, the reliance damage test returns the aggrieved party to the position occupied prior to having entered the contract."). An example of reliance-based damages is reimbursement of "expenditures [the plaintiff] made in preparation for performance or in performance.” RESTATEMENT (SECOND) OF CONTRACTS § 349 (1981).

17. Andersen, supra note 7, at 13 ("Expectation, therefore, may exceed reliance, but not vice versa; the expectation interest is a ceiling on reliance damages.").

18. See id. at 14-15 (characterizing expectation interest damages as "more generous" and reliance interest damages as "equally or less generous").
} 
demonstrate the amount of expectation damages to a substantial certainty, when he expects a loss would have occurred if the contract had been performed, or when the court limits recovery to reliance damages. ${ }^{19}$

\section{B. Tort}

The types and measures of tort damages are based on the purposes of tort law. Those purposes are "(a) to give compensation, indemnity or restitution for harms; (b) to determine rights; (c) to punish wrongdoers and deter wrongful conduct; and (d) to vindicate parties and deter retaliation or violent and unlawful self-help." ${ }^{20}$ Awarded damages must carry out one or more of these purposes. ${ }^{21}$

Based on its first purpose, tort law provides for recovery of compensatory damages. The aim of compensatory damages is to put the injured party "in a position substantially equivalent in a pecuniary way to that which he would have occupied had no tort been committed,",22 thus making the plaintiff whole. ${ }^{23}$ Compensatory damages do not include any amount "in excess of the damages [the plaintiff] has suffered" because the "plaintiff is entitled to be made whole and nothing more." 24 Compensatory damages in tort thus do not confer a windfall on the plaintiff. $^{25}$

19. See Restatement (SECOND) OF CONTRACTS $\$ 349 \mathrm{cmts}$. a \& b.

20. RESTATEMENT (SECOND) OF TORTS $\S 901$ (1979). Tort law allows recovery of nominal damages to fulfill the second purpose of tort law, the determination of rights. $I d$. $\S 901 \mathrm{cmt}$. b.

21. Id. $\S 901 \mathrm{cmt}$. a. Like the damages available for breach of contract, a plaintiff should also be able to recover consequential damages in tort. Id. §917 ("One who tortiously harms the person or property of another is subject to liability for damages for the consequences of the harm in accordance with the rules on whether the conduct is a legal cause of the consequences.").

22. Id. $\S 903 \mathrm{cmt}$. a.

23. E.g., Lovelace Med. Ctr. v. Mendez, 805 P.2d 603, 616 (N.M. 1991) ("The purpose of compensatory damages [in tort law] is to make an injured person whole."); Columbus Fin., Inc. v. Howard, 327 N.E.2d 654, 658 (Ohio 1975) ("In a tort action, the measure of damages is normally that amount of money which will compensate and make whole the injured party."); Overstreet v. Shoney's, Inc., 4 S.W.3d 694, 703 (Tenn. Ct. App. 1999) ("The purpose of tort damages in AngloAmerican law is to compensate the wronged party for damage or injury caused by the defendant's conduct. The goal of awarding damages is to repair the wronged party's injury, or, at least, to make the wronged party whole as nearly as may be done by an award of money." (citations omitted)); Schickling v. Aspinall, 369 S.E.2d 172, 174 (Va. 1988) (explaining that the purpose of compensatory damages is to make the plaintiff whole but not more than whole); DeNike v. Mowery, 418 P.2d 1010, 1019 (Wash. 1966) (explaining that the fundamental purpose of tort law is to make the plaintiff "as nearly whole as possible through pecuniary compensation").

24. Brown v. Valley Nat'l Bank of Ariz., 549 P.2d 1056, 1058 (Ariz. Ct. App. 1976); see also Bondi v. Citigroup, Inc., No. BER-L-10902-04, 2005 WL 1284041, at*8 (N.J. Super. Ct. App. Law Div. May 31, 2005) ("As a general rule, a party may not... be made more than whole by compensation that exceeds the actual damages sustained.").

25. See, e.g., Mesirow v. Leiserv, Inc., No. CIV 04-2052 PHX RCB, 2005 WL 6271135, at *4 
Based on the third and fourth purposes of tort law, punitive damages are available in some tort claims. ${ }^{26}$ The aim of punitive damages is to punish and deter the defendant wrongdoer. ${ }^{27}$ In certain torts, punitive damages may be awarded to punish the defendant for his conduct and to deter him and others from committing similar conduct in the future. ${ }^{28}$ Punitive damages are proper when the defendant's conduct is outrageous, whether because of his "evil motive or his reckless indifference to the rights of others." 29

\section{COURTS' AdOPTION OF THE BENEFIT-OF-THE-BARGAIN MEASURE OF DAMAGES FOR FRAUDULENT MISREPRESENTATION}

Today, the most common measure of compensatory damages for the tort of fraudulent misrepresentation is benefit-of-the-bargain damagesthe same as expectation interest compensatory damages for breach of contract. In the fraudulent misrepresentation context, the benefit-of-thebargain measure of damages allows the plaintiff to recover the difference in value of the property as represented by the defendant and the value of the property the plaintiff ultimately received. ${ }^{30}$ Under this measure, the plaintiff "will have no loss" and "will achieve any economic gains he would have had if the representations had been correct." 31

\section{A. Majority Rule at the Beginning of the Twentieth Century}

One of the earliest cases in which the court allowed benefit-of-thebargain damages for fraud was Stiles $v$. White, which involved a

(D. Ariz. Dec. 1, 2005) (explaining that the purpose of compensatory damages in tort does not include conferring a windfall on the plaintiff); McAuley v. Gen. Motors Corp., 578 N.W.2d 282, 285 (Mich. 1998) ("Because the purpose of compensatory damages is to make the injured party whole for the losses actually suffered, the amount of recovery for such damages is inherently limited by the amount of the loss [and] the party may not make a profit . . .." (emphasis added)).

26. RESTATEMENT (SECOND) OF TORTS $\S 901 \mathrm{cmt}$. c.

27. Id. Unlike contract law, tort law encompasses the ideas of punishment and deterrence. Id.

28. Id. $\S 908(1)$.

29. Id. $\S 908(2)$. Some states control the availability of punitive damages by statute. See, e.g., infra note 232 and accompanying text. Punitive damages are generally not available for breach of contract, but if the plaintiff has the ability to sue for both tort and breach of contract, the "fact that [the defendant's] act or omission amounts to a breach of contract does not preclude the award of punitive damages if the action is brought for the tort and the tort is one for which punitive damages are proper." RESTATEMENT (SECOND) OF TORTS $§ 908 \mathrm{cmt}$. b.

30. Effectively, benefit-of-the-bargain damages make the representation true by awarding an amount equivalent to the value of the good as the defendant represented. See infra notes 131-33 and accompanying text.

31. 2 DoBBS, supra note $7, \S 9.2(1)$, at 551 . 
misrepresentation regarding the value of a horse. ${ }^{32}$ The court affirmed the trial court's instruction that the measure of damages was the difference between the actual value of the horse and the value of the horse as represented by the defendants. ${ }^{33}$ The court also noted that this is the measure of damages for breach of warranty and that the measure of damages for fraudulent misrepresentation should be the same: "[S]urely the defendants cannot claim a more favorable rule of damages[] on the ground of their own fraud." 34 The court "discerned a moral barrier against fixing a lesser measure, [because of] the gain to the defrauding party which would result from fraud if a lesser measure were adopted for fraud." 35

Over time, the benefit-of-the-bargain measure of damages for fraudulent misrepresentation became well-settled Massachusetts law. ${ }^{36}$ Massachusetts courts considered the measure as "the only rule which will give the purchaser adequate damages for not having the thing which the defendant undertook to sell him" and the only way to benefit the innocent plaintiff instead of the wrongdoer. ${ }^{37}$ After 1870, numerous other states adopted the benefit-of-the-bargain damages measure for fraud claims, and commentators began to advocate the benefit-of-thebargain measure. ${ }^{38}$

By 1918, the benefit-of-the-bargain measure of damages for fraudulent misrepresentation was the majority rule. ${ }^{39}$ In Hallen $v$. Martin, the South Dakota Supreme Court found that the majority rule was "sounder" and was the only measure that puts the plaintiff in the same place as if the fraud had not occurred by awarding the plaintiff "his actual loss by reason of the fraud of the seller." ${ }^{, 40}$ Further, the court agreed that the benefit-of-the-bargain measure of damages was necessary to ensure that "'any advantage lawfully secured to the innocent purchaser

32. 52 Mass. (11 Met.) 356, 356 (1846).

33. Id. at 358 .

34. Id.

35. Gary L. Monserud, Measuring Damages After Buyer's Affirmation of an Article 2 Sales Contract Induced by Fraud: A Study of Code Jurisprudence in Light of Section 2-721 and Pre-code Conflicts in Remedial Theory, 1996 COLUM. Bus. L. REV. 423, 432.

36. See Morse v. Hutchins, 102 Mass. 439, 440 (1869).

37. Id.

38. Monserud, supra note 35, at 434-35 (discussing that Massachusetts, New Hampshire, North Dakota, Colorado, Nebraska, and Georgia adopted the benefit-of-the-bargain measure of damages for fraudulent misrepresentation).

39. See Hallen v. Martin, 167 N.W. 314, 319 (S.D. 1918) (Smith, J., concurring) (noting that thirty-four states followed the benefit-of-the-bargain rule in 1918).

40. Id. at 315 . 
in the original bargain [not] inure to the benefit of the wrongdoer.",41 The use of a measure yielding lesser damages would "place a premium on fraud and deceit[] because oftentimes the defendant ... would get out much easier by virtue of his fraud and deceit than if he had only been guilty of a breach of contractual warranty." ${ }^{42}$ The concurring opinion in Hallen noted that fraud and breach of warranty causes of action should have identical measures of compensatory damages. ${ }^{43}$

\section{B. Minority Rule at the Beginning of the Twentieth Century}

Not all jurisdictions embraced the benefit-of-the-bargain measure, however, including the federal courts. This minority of jurisdictions instead adopted the out-of-pocket damages measure.

The English court of appeal first addressed the issue of the damages recoverable for fraudulent misrepresentation in Peek v. Derry, where the plaintiff was induced to purchase stock as a result of misrepresentations. ${ }^{44}$ The court defined the applicable measure of damages as the plaintiff's out-of-pocket losses, meaning the difference between the purchase price and the value of the good received. ${ }^{45}$ This was the amount that the plaintiff was "worse off" due to his purchase of the shares, and this was the loss that the plaintiff sustained by acting on the misrepresentation. ${ }^{46}$

The United States Supreme Court adopted this logic in Smith $v$. Bolles. ${ }^{47}$ The Court found that that the defendant who misrepresented the value of stock was liable for damages that "naturally and proximately resulted from the fraud" and thus "was bound to make good the loss

41. Id. at 316 (quoting Morse, 102 Mass. at 440).

42. Id.

43. Id. at 319 (Smith, J., concurring).

44. [1888] 37 Ch.D. 541 at 542 (Eng.).

45. Id. at 591. As explained by Lord Justice Cotton:

The damage to be recovered by the Plaintiff is the loss which he sustained by acting on the representations of the Defendants. That action was taking the shares. Before he was induced to buy the shares, he had the $£ 4000$ in his pocket. The day when the shares were allotted to him, which was the consequence of his action, he paid over that $£ 4000$, and he got the shares; and the loss sustained by him in consequence of his acting on the representations of the Defendants was having the shares, instead of having in his pocket the $£ 4000$. The loss, therefore, must be the difference between his $£ 4000$ and the then value of the shares.

Id.

46. Id. at 594 ("The question is, how much worse off is the Plaintiff than if he had not bought the shares? If he had not bought the shares he would have had his $£ 4000$ in his pocket. To ascertain his loss we must deduct from that amount the real value of the thing he got." (Sir. Hannen)).

47. 132 U.S. 125 (1889). 
sustained." of an unrealized speculation" because "[w] hat the plaintiff might have gained is not the question, but what he had lost by being deceived into the purchase." $" 49$

The Supreme Court again limited damages for fraudulent misrepresentation to out-of-pocket losses in Sigafus v. Porter. ${ }^{50}$ The Court stated that the out-of-pocket-losses measure compensates the plaintiff for the amount of " "money he has parted with without receiving an equivalent therefor." 51 The plaintiff's "“actual loss does not include the extravagant dreams which prove illusory." ${ }^{, 52}$ Any such damages would be something other than compensatory and thus not available. ${ }^{53}$

Following the lead of the Supreme Court, some state courts adopted the minority out-of-pocket-losses measure of damages. ${ }^{54}$ For example, the Supreme Court of Minnesota refused to consider the represented value of land because "the action was in tort." 55 The court declared that the defendant was liable for those damages that "naturally and proximately resulted from the fraud," meaning the out-of-pocket losses actually sustained. ${ }^{56}$

\section{The First Restatement of Torts}

In 1938, the First Restatement of Torts adopted the minority rule measure of damages for fraudulent misrepresentation within business transactions and allowed compensatory damages based on "the difference between the value of the thing bought, sold or exchanged and its purchase price or the value of the thing exchanged for it." ${ }^{, 57}$

\footnotetext{
48. Id. at 129 .

49. Id. at 129-30. The Court further clarified that the question of what the plaintiff might have gained was irrelevant because the claim was not for breach of contract. Id. at 129 .

50. 179 U.S. 116 (1900).

51. Id. at 124 (quoting High v. Berret, 23 A. 1004, 1004 (Pa. 1892)).

52. Id. (quoting High, 23 A. at 1004).

53. See id.

54. See, e.g., George v. Hesse, 93 S.W. 107, 107 (Tex. 1906) (holding that the extent of the plaintiff's loss due to the fraudulent misrepresentation was "the difference between the value of that which he has parted with, and the value of that which he has received under the agreement").

55. Reynolds v. Franklin, 46 N.W. 139, 139 (Minn. 1890).

56. Id.

57. RESTATEMENT (FIRST) OF TORTS $\S 549$ (a) (1938). This provision also allows recovery of consequential damages. Id. § 549(b). For a discussion of the conflict between the First Restatement's measure of damages for fraudulent misrepresentation and the majority test used by the courts, see generally John Hannigan, The Measure of Damages in Tort for Deceit, 18 B.U. L. REV. 681 (1938).

The First Restatement differentiates based on whether the misrepresentation occurs within a
} 
The First Restatement prohibited the recovery of benefit-of-thebargain damages for fraudulent misrepresentation: "The fact that [a party] would have made a profit if the representation had been true does not entitle him to recover for his disappointment in not receiving the gain which he was led to expect." ${ }^{, 58}$ According to the First Restatement, if the party wanted to recover damages based on his expected gain, the party was free to waive the fraud claim and instead pursue relief based on a breach-of-warranty theory. ${ }^{59}$

The First Restatement acknowledged that "the remedy for deceit and the remedy for breach of warranty have been procedurally closely interwoven" and that "the liabilities for fraudulent misstatements and intentional nondisclosure have been assimilated to the liability for breach of warranty." ${ }^{\prime 60}$ The necessary response to this assimilation, according to the First Restatement, was to limit damages for fraudulent misrepresentation "to the loss sustained." 61

\section{The Second Restatement of Torts}

Perhaps motivated by the popularity of the benefit-of-the-bargain measure of damages, the authors of the Second Restatement of Torts, published in 1977, did an about-face. ${ }^{62}$ Instead of limiting damages due

business transaction. RESTATEMENT (FIRST) OF TORTS div. 4, ch. 22, scope note. A "business transaction" is "any action which affects the plaintiff's financial or economic interests," including "not only the making of a contract, but also any action done in its performance." Id. The rules applying to representations within business transactions should differ from those applying in nonbusiness transactions because "the ethics of bargaining" affect the rules. Id. Courts' tendency "has been to relax the requirement of vigilance against deception but there is no tendency to require commercial or financial adversaries to lay all their cards on the table face upward when dealing with one another." Id.

58. Id. $\S 549$ cmt. b.

59. Id. The comments to section 549 also make clear that a party should pursue relief on a breach-of-warranty theory to recover benefit-of-the-bargain damages:

If the fraudulent misrepresentation is so made as to constitute a warranty, the person acting in reliance upon it may waive the fraud and bring an action on the warranty in which case the measure of damages is that appropriate to an action on the warranty, namely, the difference between the value of the article as it is and the value which it would have had had the fact warranted been true.

Id. $\S 549 \mathrm{cmt}$. $\mathrm{g}$. It is not clear why the party could not pursue both fraud and breach-of-warranty theories, especially in light of the ability to plead in the alternative. Ultimately, however, the damages awards would merge, assuming that damages due to the fraud and the breach were the same. See infra note 216.

60. RESTATEMENT (FIRST) OF TORTS div. 4, ch. 22, scope note.

61. See id.

62. See RESTATEMENT (SECOND) OF TORTS $§ 549 \mathrm{cmt}$. g (1977) ("The frequency of these situations [where out-of-pocket losses are supposedly insufficient] has led the great majority of the American courts to adopt a broad general rule giving the plaintiff, in an action of deceit, the benefit of his bargain with the defendant in all cases, and making that the normal measure of recovery in 
to the increasingly interwoven nature of fraudulent misrepresentation and breach-of-warranty claims, the Second Restatement embraces that interwoven nature and added the possibility of recovering benefit-of-thebargain damages for fraudulent misrepresentation. Specifically, the drafters added subsection 2 to section 549, which states: "The recipient of a fraudulent misrepresentation in a business transaction is also entitled to recover additional damages sufficient to give him the benefit of his contract with the maker, if these damages are proved with reasonable certainty." 63

The commentary clarifies that the out-of-pocket-losses measure of damages is "the rule[] normally applicable to determine the measure of damages for a fraudulent misrepresentation." 64 The out-of-pocket-losses measure of damages is also the "logical rule[] for a tort action, since the purpose of a tort action is to compensate for loss sustained and to restore the plaintiff to his former position, and not to give him the benefit of any contract he has made with the defendant." 65

According to the Second Restatement, however, out-of-pocket losses may not always provide just and satisfactory compensation. ${ }^{66}$ For instance, if the purchase price equals the value of the property plaintiff received, the plaintiff has no out-of-pocket losses even though the defendant promised that the good was worth more than the purchase price. ${ }^{67}$ In this instance, the plaintiff has no damages and "the defrauding party would escape all liability." 68

actions of deceit.").

63. Id. §549(2).

64. Id. § $549 \mathrm{cmt} . \mathrm{g}$.

65. Id.

66. Id. The Second Restatement claims that it does not go so far as to adopt the benefit-of-thebargain measure of damages for all cases. See id. $\S 549 \mathrm{cmt}$. h. The commentary's claim that the rule is flexible is curious because the provision appears to guarantee the possibility of benefit-of-thebargain damages. See id. § 549(2) ("The recipient of a fraudulent misrepresentation in a business transaction is also entitled to recover [benefit-of-the-bargain damages], if these damages are proved with reasonable certainty." (emphasis added)).

67. Id. $\S 549 \mathrm{cmt}$. g. The Second Restatement provides another example of the insufficiency of out-of-pocket losses when the good the plaintiff receives is useless to the plaintiff even though it is worth the purchase price - if the plaintiff "is left with something on his hands that he does not want and cannot use." Id. $\$ 549 \mathrm{cmt}$. j. To end up where he originally planned, the plaintiff will need to sell the good he received without incurring a loss and then still seek the good he originally wanted. Id. The purported need for benefit-of-the-bargain damages does not seem compelling, however. Damages based on the delay and costs incurred in obtaining the originally desired good should be recoverable as consequential damages. The plaintiff may not be able to purchase the good he originally desired at the same price as the deal made with the defendant. But even then, the plaintiff should be able to recover the difference in the agreed-to price and the ultimate price paid for the substitute good.

68. Id. $\S 549 \mathrm{cmt}$. g. The fear of the defrauding party escaping liability assumes that the plaintiff does not pursue relief under a breach-of-contract theory, through which the plaintiff could 
This result "is not justice between the parties." the Second Restatement allows for the recovery of benefit-of-the-bargain damages for fraudulent misrepresentation. ${ }^{70}$ "The admonitory function of the law requires that the defendant not escape liability and justifies allowing the plaintiff the benefit of his bargain." ${ }^{71}$ Thus, the Second Restatement provides for an award of benefit-of-the-bargain damages to admonish the defendant.

\section{E. Current Availability of Benefit-of-the-Bargain Damages for Fraudulent Misrepresentation}

Just as in the beginning of the twentieth century and consistent with the Second Restatement, the vast majority of states allow the plaintiff to recover benefit-of-the-bargain-based compensatory damages for fraudulent misrepresentation. ${ }^{72}$ The second most popular measure is a flexible approach, applying either benefit-of-the-bargain or out-of-pocket damages depending on which measure is fair and equitable. ${ }^{73}$ This compromise position still allows recovery of benefit-of-the-bargain damages for fraudulent misrepresentation. ${ }^{74}$ Thus, at least eighty percent

recover both benefit-of-the-bargain-based compensatory damages and nominal damages. The purpose of nominal damages is to recognize that a wrong occurred even though the plaintiff lacks actual damages. Nominal damages are not recoverable for fraudulent misrepresentation because the tort requires the plaintiff to have suffered actual damages. See W. Page KeEton et AL., Prosser AND KEETON ON THE LAW OF TORTS $\S 110$, at 765 (5th ed. 1984). The idea that the defendant escapes liability if the plaintiff lacks actual damages is flawed because it presumes liability. To the contrary, liability is not possible if the plaintiff lacks actual damages. Instead of the defendant escaping liability if the plaintiff lacks actual damages, the defendant is simply not liable because the plaintiff cannot establish one of the elements of the fraudulent misrepresentation claim.

69. RESTATEMENT (SECOND) OF TORTS $§ 549 \mathrm{cmt}$. i.

70. The Restatement also clarifies that the plaintiff may not always be entitled to "the value of the thing as represented." Id. $\S 549 \mathrm{cmt}$. 1 . The type of damages recoverable will depend on the type of bargain. Id. If the defendant promised to convey a specifically described good, "the plaintiff is entitled to an amount sufficient to give him the value of property of that description." Id. If the defendant promised to convey accurate information regarding the good, the plaintiff "is entitled to a sufficient amount to place him in the position he would have occupied if he had had the information." Id.

71. Id. $\S 549 \mathrm{cmt}$. i. For a discussion of whether the fear of the defendant escaping liability is flawed, see infra note 119.

72. See Lawrence v. Forthun, No. A09-543, 2009 WL 4796754, at *4 (Minn. Ct. App. Dec. 15, 2009) (mentioning that the majority rule for compensatory damages for fraudulent misrepresentations is the benefit-of-the-bargain measure); Lightning Litho, Inc. v. Danka Indus., Inc., 776 N.E.2d 1238, 1241-42 (Ind. Ct. App. 2002) (same); see also RESTATEMENT (SECOND) OF TORTS $\S 549$ reporter's note 3 (counting thirty-two states following the benefit-of-the-bargain approach).

73. See RESTATEMENT (SECOND) OF TORTS $\S 549$ reporter's note 1 (counting eight states following the compromise approach).

74. Annotation, supra note 2, at 927-28 (discussing that some jurisdictions will apply either the out-of-pocket losses or the benefit-of-the-bargain measures of damages, depending on which 
of states allow the recovery of benefit-of-the-bargain-based compensatory damages for fraudulent misrepresentation.

A small minority of states agrees with the First Restatement of Torts and prohibits benefit-of-the-bargain damages for fraudulent misrepresentation. ${ }^{75}$ In these states, the plaintiffs can recover only their out-of-pocket losses for fraudulent misrepresentation.

\section{F. Rejection of Benefit-of-the-Bargain Damages for Negligent Misrepresentation}

Despite the widespread acceptance of awarding benefit-of-thebargain damages for fraudulent misrepresentation, both the majority of courts and the Second Restatement of Torts agree that benefit-of-thebargain damages are not available in a claim for negligent misrepresentation. $^{76}$ Per the Second Restatement, this rejection is consistent with the "general rule [of] no liability for merely negligent conduct that interferes with or frustrates a contract interest or an expectancy of pecuniary advantage.".77

\section{WHAT’S THE DisTINCTION BETWEEN CONTRACT AND TORT AGAIN?}

The majority of states allow the exact same measure of compensatory damages for both breach-of-contract and fraudulent misrepresentation actions. ${ }^{78}$ The similarity in damages available is but

measure will achieve the "fair and equitable result").

75. RESTATEMENT (SECOND) OF TORTS $\S 549$ reporter's note 2 (counting six states following the out-of-pocket approach). Plaintiffs may also recover consequential damages for fraudulent misrepresentation regardless of whether the jurisdiction awards benefit-of-the-bargain or out-ofpocket-losses damages. Consequential damages include "pecuniary loss suffered ... as a consequence of the recipient's reliance upon the misrepresentation." Id. $\S 549(1)(b)$. Generally, these damages are available for both breach-of-contract and tort actions, although the damages may be more difficult to recover for breach of contract because the parties must contemplate the damages at the time the contract was made. See William Lloyd Prosser, SElected Topics on the LAW OF TORTS 425-26 (1954). This Article does not take issue with the ability of a plaintiff to recover consequential damages for fraudulent misrepresentation; the availability of consequential damages is assumed and not discussed.

76. Restatement (SECOND) OF TORTS $§ 552 \mathrm{~B}(2)$; see also BDO Seidman, LLP v. Mindis Acquisition Corp., 578 S.E.2d 400, 401 (2003) (explaining that a majority of jurisdictions follow the Second Restatement of Torts and limit damages for negligent misrepresentation to out-of-pocket losses because it is "commensurate with the culpability of the [defendant]").

77. RESTATEMENT (SECOND) OF TORTS $\S 552 \mathrm{~B} \mathrm{cmt}$. b.

78. Benefit-of-the-bargain damages for fraudulent misrepresentation are "exactly like the expectancy measure of contract damages." 2 DOBBS, supra note 7, $\$ 9.2(1)$, at 551. If state law restricts the recovery of damages for fraudulent misrepresentation to out-of-pocket losses, "the plaintiff will be better off to recover for contract or warranty breach than for deliberate fraud." Id. $\S 9.2(1)$, at 549 . 
one of the factors creating confusion between contract and tort actions. ${ }^{79}$ A plaintiff would be foolish to not plead both causes of action, leaving the court to determine if only the breach-of-contract or tort action is proper. Courts have developed numerous analyses to aid in this determination.

\section{A. Focus on the Source of the Alleged Duty Owed}

Numerous courts focus on the source of the alleged duty owed by the defendant. If the duty is based in the contract itself, then the claim is for a breach of contract. ${ }^{80}$ But if the duty is based on something outside of the contract, the duty is based in tort law and the claim is for a tort. ${ }^{81}$ To determine if the duty is based in the contract, the court need not look any further than the contract itself. The duties that result from the contract are those "imposed by mutual consensus agreements between particular individuals." 82 Thus, contract law is individualistic - the parties define the duties owed.

The source of duties owed in tort law is less definite. To determine if the duty is based in tort, the court must look to whether the law imposes a duty as a result of social policy:

Tort obligations are in general obligations that are imposed by law ... to avoid injury to others. By injury here is meant simply the interference with the individual's interest .... The variety of interests that are protected through tort law in one way or another are divisible into three general categories: (1) interests of personality; (2) interests in

79. For a discussion on the confusion between contract and tort, see PROSSER, supra note 75, at 386. In his book, The Death of Contract, Professor Grant Gilmore argued that the distinction between contract and tort law is not merely confused but instead nonexistent. See generally GranT GILMORE, THE DEATH OF CONTRACT (1974) (arguing that contract law is dissolving into tort law). As evidence of the dissolution of contract law into tort law, Gilmore pointed to the similarity in the recoverable damages of both. See id. at 88 ("We may take the fact that damages in contract have become indistinguishable from damages in tort as obscurely reflecting an instinctive, almost unconscious realization that the two fields, which had been artificially set apart, are gradually merging and becoming one.").

80. See, e.g., Wages v. Young, 261 S.W.3d 711, 715 (Mo. Ct. App. 2008).

81. See, e.g., id. Texas courts define the distinction between the duties owed as follows:

If the defendant's conduct — such as negligently burning down a house-would give rise to liability independent of the fact that a contract exists between the parties, the plaintiff's claim may also sound in tort. Conversely, if the defendant's conduct - such as failing to publish an advertisement-would give rise to liability only because it breaches the parties' agreement, the plaintiff's claim ordinarily sounds only in contract.

Sw. Bell Tel. Co. v. DeLanney, 809 S.W.2d 493, 494 (Tex. 1991).

82. Chemtech Int'l, Inc. v. Chem. Injection Techs., Inc., No. 05-2296, 2006 WL 690837, at *3 (3d Cir. Mar. 20, 2006) (quoting Sullivan v. Chartwell Inv. Partners, 873 A.2d 710, 719 (Pa. Super. Ct. 2005)). 
tangible things, real and personal; and (3) a large body of intangible interests, both economic and relational.

Whether a duty exists in tort generally depends on (1) the nature of the defendant's activity, (2) the relationship between the plaintiff and the defendant, and (3) the type of injury or harm threatened. ${ }^{84}$

The focus on the source of the duty distinction has little utility in the context of fraudulent misrepresentation. Technically, the plaintiff need not establish the existence of a duty in a fraudulent misrepresentation claim. ${ }^{85}$ This is because the duty of honesty is implicit within the transaction. ${ }^{86}$ Courts have, however, sometimes refused to allow fraudulent misrepresentation claims when a contractual duty exists. ${ }^{87}$

\section{B. Focus on the Type of Loss}

In addition to the question of the source of the duty, some courts look to the nature of the claimed damages to determine whether a claim is for breach of contract or tort. "[T] ort law affords a remedy for losses occasioned by personal injuries or damage to one's property, but contract law ... offer[s] the appropriate remedy for economic losses occasioned by diminished commercial expectations not coupled with injury to

83. KeEtON ET AL., supra note 68, at 655; see also Bash v. Bell Tel. Co. of Pa., 601 A.2d 825, 829 (Pa. Super. Ct. 1992) (explaining that tort duties are "imposed by law as a matter of social policy”), superseded by rule on other grounds, PA. R. APP. P. § 314, as recognized in Lombardi v. Allstate Ins. Co., No. 08-949, 2009 WL 1811540, at *10 (W.D. Pa. June 23, 2009).

84. KEETON ET AL., supra note $68, \S 92$, at 655 .

85. Specifically, unlike in a claim for negligent misrepresentation, the plaintiff need not establish that the defendant owed a duty of care within a fraudulent misrepresentation claim. Even within negligent misrepresentation, however, the duty of care is presumed if the defendant had a pecuniary interest in supplying the information at issue to the plaintiff. See infra note 121.

86. As the Second Restatement explains:

Honesty requires only that the maker of a representation speak in good faith and without consciousness of a lack of any basis for belief in the truth or accuracy of what he says. The standard of honesty is unequivocal and ascertainable without regard to the character of the transaction in which the information will ultimately be relied upon or the situation of the party relying upon it. Any user of commercial information may reasonably expect the observance of this standard by a supplier of information to whom his use is reasonably foreseeable.

RESTATEMENT (SECOND) OF TORTS $\S 552 \mathrm{cmt}$. a (1977) (emphasis added).

87. See Pandjiris, Inc. v. Sunshine Stainless Tank \& Equip. Co., 655 F. Supp. 473, 474 (E.D. Mo. 1987) (rejecting fraudulent misrepresentation counterclaim because it was "[nothing] more than a recasting of its claim for breach of contract as a tort"). This result in Pandjiris appears inconsistent with the Second Restatement. See Restatement (SECOnd) OF TorTs $\$ 530 \mathrm{cmt}$. c (explaining that if the underlying contract is enforceable, "the person misled by the representation has a cause of action in tort as an alternative at least, and perhaps in some instances in addition to his cause of action on the contract"). 
person or property." 88 At the same time, specific to fraudulent misrepresentations, tort law traditionally governs losses suffered due to reliance on representations. ${ }^{89}$

Usually reaching the same result, some courts prefer to look at the cause of the claimed damages: "When the only loss or damages is to the subject matter of the contract, the plaintiff's action is ordinarily on the contract." ${ }^{90}$ Claimed benefit-of-the-bargain damages would likely relate to the subject matter of the contract and thus not be available in tort. ${ }^{91}$ If applied strictly, this analysis would effectively end the ability to recover benefit-of-the-bargain damages for fraudulent misrepresentation. ${ }^{92}$ To recover benefit-of-the-bargain damages, the plaintiff would have no choice but to sue for breach of contract.

\section{The Economic-Loss Doctrine}

The economic-loss doctrine, a judicial creation, attempts to distinguish between contract and tort actions by limiting the recovery of economic losses to breach-of-contract actions. ${ }^{93}$ Economic losses can include both out-of-pocket losses and benefit-of-the-bargain damages. ${ }^{94}$ Per the economic-loss doctrine, the plaintiff cannot recover economic losses in tort, meaning a plaintiff can bring a claim for economic losses only if the plaintiff had contractual privity with the defendant. ${ }^{95}$

The economic-loss doctrine "defines the boundary between the overlapping theories of tort law and contract law by barring the recovery of purely economic losses in tort, particularly in strict liability and

88. Mars, Inc. v. Heritage Builders of Effingham, Inc., 763 N.E.2d 428, 434 (Ill. App. Ct. 2002); see also KEETON ET AL., supra note 68, § 92, at 657 ("Recovery of intangible economic losses is normally determined by contract law.").

89. See KeETON ET AL., supra note $68, \S 92$, at 658.

90. Sw. Bell Tel. Co. v. DeLanney, 809 S.W.2d 493, 494 (Tex. 1991); see also Jim Walter Homes, Inc. v. Reed, 711 S.W.2d 617, 618 (Tex. 1986) ("When the injury is only the economic loss to the subject of a contract itself, the action sounds in contract alone.").

91. See Mars, Inc., 763 N.E.2d at 434 ("A buyer's desire to enjoy the benefit of his bargain is not an interest that tort law traditionally protects.").

92. See Charles Miller, Contortions over Contorts: A Distinct Damages Requirement?, 28 TEX. TECH L. REV. 1257, 1276-77 (1997) (arguing that a distinct damages requirement would effectively preclude any fraud action involving a contract).

93. See, e.g., Bernot v. Primus Corp., 663 N.E.2d 464, 467 (Ill. App. Ct. 1996) ("Under the Moorman doctrine, recovery for economic loss - the loss of the benefit of one's bargain - ordinarily is available only in contract and not in tort.").

94. R. Joseph Barton, Note, Drowning in a Sea of Contract: Application of the Economic Loss Rule to Fraud and Negligent Misrepresentation Claims, 41 WM. \& MARY L. REV. 1789, 1793-94 (2000).

95. See Bernot, 663 N.E.2d at 467 ("With exceptions not pleaded or applicable here, a viable action for economic loss requires the plaintiff to be in contractual privity with [the defendant]."). 
negligence cases."96 Similarly, the economic-loss doctrine defines a distinction between the types of damages recoverable in tort and in contract. $^{97}$ By defining that distinction, the economic-loss doctrine "prevent[s] the law of contract and the law of tort from dissolving one into the other." 98

Problematically, "blind application of the [economic-loss] doctrine... would eviscerate fraud and negligent misrepresentation claims." "99 Due to this conflict, courts have had trouble resolving whether the economic-loss rule should apply to fraudulent misrepresentation claims. Courts have crafted three approaches: adopting an exception to the economic-loss doctrine for fraudulent misrepresentation claims, ${ }^{100}$ allowing fraudulent misrepresentation claims to proceed only if the alleged fraud is not also related to the contract, ${ }^{101}$ and applying the doctrine to preclude fraudulent misrepresentation claims. ${ }^{102}$

96. Barton, supra note 94, at 1789 . The reasoning behind the economic loss doctrine is that "tort law is not intended to compensate parties for monetary losses suffered as a result of duties which are owed to them simply as a result of the contract." Tyler v. Gibbons, 857 N.E.2d 885, 888 (Ill. App. Ct. 2006).

97. The economic-loss rule is inconsistent with traditional thought that losses, including economic losses, suffered due to reliance on representations should be recoverable and controlled by tort law. See supra note 89 and accompanying text.

98. Rich Prods. Corp. v. Kemutec, Inc., 66 F. Supp. 2d 937, 969 (E.D. Wis. 1999).

99. Barton, supra note 94 , at 1824 .

100. See id. at 1831 (explaining that most states recognize an exception to the economic-loss rule for fraud).

101. See id. at 1806-11.

102. See id. at 1811-12; see also Orlando v. Novurania of Am., Inc., 162 F. Supp. 2d 220, 22526 (S.D.N.Y. 2001) (dismissing fraudulent misrepresentation claim based on New York's economicloss doctrine where the only damages sought for the fraudulent misrepresentation were based on the benefit of the bargain). Courts experience the same trouble resolving whether the economic-loss doctrine should apply to negligent misrepresentation claims. Courts have crafted four main approaches: adopting an exception to the economic-loss doctrine for negligent misrepresentation claims, allowing the claim to proceed only if the defendant is in the business of supplying information, allowing the claim to proceed only if the plaintiff is not in contractual privity with the defendant, and applying the doctrine to preclude the negligent misrepresentation claim. Barton, supra note 94, at 1814-23. Illinois courts developed the second approach, allowing the claim to proceed only against those defendants in the business of supplying information. See Tyler v. Gibbons, 857 N.E.2d 885, 888-89 (Ill. App. Ct. 2006). In Tyler, the defendants were the board of directors of a company that provided products to agricultural producers. Id. The plaintiffs were thus unable to proceed on a claim of negligent misrepresentation because the defendants were not in the business of providing financial information. Id. If all states interpreted the negligent misrepresentation claim so narrowly, the economic-loss doctrine would likely maintain a distinction in the damages available for contract and negligence. Neither the Restatement nor states other than Illinois, however, have adopted such a narrow interpretation. See Barton, supra note 94, at 1819-22. The third approach, allowing the claim to proceed only if the parties are not in contractual privity, maintains the distinction between tort and contract because the negligent misrepresentation tort will be available only when the contract claim is not. This limited application is not consistent, however, with the idea that economic losses should be recovered in contract claims only. Moreover, the problem with allowing the negligent misrepresentation claim to proceed when no contract exists is 


\section{Time to Be Honest: BenEFIT-OF-THE-BARgAin DAMAGES IN TORT ARE SOMETHING MORE THAN COMPENSATORY}

Benefit-of-the-bargain damages put the plaintiff in a better position than he was in before the tort, rendering these damages something other than compensatory. The unavailability of benefit-of-the-bargain damages for negligent misrepresentation further evidences the inappropriateness of classifying the damages as compensatory.

\section{A. Benefit-of-the-Bargain Damages Make the Plaintiff More than Whole by Conferring a Windfall}

In tort law, compensatory damages look back to the plaintiff's position before the misrepresentation and give the plaintiff an amount that will put him in that same position. ${ }^{103}$ Borrowing from the facts of Peek, suppose that the defendant misrepresents the value of stock. ${ }^{104}$ The plaintiff desires to purchase stock as a result. The plaintiff has $\$ 500$ in his pocket before he purchases the stock, which he uses to purchase the stock from the defendant, but the stock is worth only $\$ 400$. Before the misrepresentation, the plaintiff has $\$ 500$, but after the transaction, the plaintiff has stock worth only $\$ 400$. Compensatory damages should total $\$ 100$, the amount necessary to put the plaintiff in the same place that he was in before the misrepresentation when he had $\$ 500$ in his pocket.

Benefit-of-the-bargain damages, however, give the plaintiff more. Again borrowing from Peek, suppose that the defendant represented the stock to be worth $\$ 700$. The plaintiff had $\$ 500$ before the transaction and still has stock worth $\$ 400$ after the transaction. Benefit-of-thebargain damages, however, would give the plaintiff $\$ 300 .^{105}$

Had there been no deceit, the plaintiff would not have the $\$ 200$. Similarly, had there been no deceit, the plaintiff would not have expected to make a $\$ 200$ profit. $^{106}$ In fact, had there been no deceit, the plaintiff

that the plaintiff may be able to avoid rules like the statute of frauds. See ProsSER, supra note 75, at 422-29 (explaining the important consequences in choosing to proceed with a contract or tort claim, including that the tort claim is not subject to the statute of frauds).

103. See supra notes 22-25 and accompanying text.

104. Peek v. Derry, [1888] 37 Ch.D. 541 (Eng.). See generally supra notes 44-46 and accompanying text.

105. See Chavarria v. Fleetwood Retail Corp. of N.M., 115 P.3d 799, 807 (N.M. Ct. App. 2005) (explaining that courts award benefit-of-the-bargain damages for fraud even if the actual loss suffered might have been much less), rev'd in part, 143 P.3d 717 (N.M. 2006).

106. This illustrates the difference between the ending positions of compensatory damages in tort and breach of contract. In tort, the plaintiff has no expectation before the misrepresentation occurs and tort-based compensatory damages thus should not consider the lost expectation. 
would have $\$ 500$ in his pocket, not contemplating-much less expecting - to make a profit by purchasing stock from the defendant.

Benefit-of-the-bargain damages, however, mean that the plaintiff now has $\$ 700$ - the value of the stock $(\$ 400)$ and the damages $(\$ 300)$ even though the plaintiff had only $\$ 500$ before the misrepresentation. No one can disagree that the benefit-of-the-bargain damages thus put the plaintiff "in better shape financially than he would have been in if there had been no deceit." 107 Similarly, no one can disagree that this plaintiff received a financial windfall — basically a gift of $\$ 200$. By definition, however, compensatory damages do not confer a windfall. ${ }^{108}$

This hypothetical is just one example of the many cases where benefit-of-the-bargain damages make the plaintiff better off than before the tort. In Leftwich $v$. Gaines, the plaintiff wanted to purchase property to expand her business. ${ }^{109}$ She made an offer to purchase it for $\$ 10,000$ but heard nothing from the seller. ${ }^{110}$ After the offer, a municipality official misrepresented to the plaintiff that the property may not be able to be rezoned and that her offer was too high. ${ }^{111}$ The seller ultimately accepted a bid from someone associated with the same municipality official. $^{112}$ At trial, the plaintiff sought damages for the fraudulent misrepresentation based on her disappointed expectations; she testified that she would have had property worth $\$ 120,000$ had she been able to purchase the property she desired. ${ }^{113}$

Before the alleged misrepresentation, the plaintiff owned property worth $\$ 50,000 .^{114}$ After the misrepresentation, she still owned property worth $\$ 50,000 .{ }^{115}$ The plaintiff was still in the same position both before and after the misrepresentation. Despite her lack of out-of-pocket losses, the North Carolina Court of Appeals affirmed a compensatory damage award of $\$ 60,000$ based on the "loss of the property value" to the

Expectation-interest damages in contract, however, put the plaintiff in the same position as if the contract had not been breached. See supra Part II.A.1. The plaintiff's expectation exists before the breach, and contract law compensates for that lost expectation.

To avoid the problem caused by the rule that tort damages look to the position the plaintiff was in before the tort, advocates of benefit-of-the-bargain damages claim that the falsity of the misrepresentation constitutes the tort instead of the misrepresentation itself. See infra note 132 and accompanying text. For an argument discrediting this conceptual separation, see infra notes 132-33.

107. Hallen v. Martin, 167 N.W. 314, 321 (S.D. 1918) (Whiting \& Gates, JJ., dissenting).

108. See supra note 25 and accompanying text.

109. 521 S.E.2d 717, 721 (N.C. Ct. App. 1999).

110. Id.

111. Id. at $721-22$.

112. Id.

113. Id. at 725 .

114. Id.

115. See id. 
plaintiff. ${ }^{116}$ The court's characterization of the plaintiff's damages as a "loss" is remarkable because the plaintiff never owned nor had any contractual claim to the adjoining property, ${ }^{117}$ but the damages gave her the value of that adjoining property.

How could the plaintiff be entitled to compensatory damages based on the loss of something that she never had? That is exactly what benefit-of-the-bargain damages do-give plaintiffs something they did not have before the misrepresentation. By definition then, benefit-of-thebargain damages cannot be compensatory in tort because they put plaintiffs in a better position than before the misrepresentation and, similarly, confer a financial windfall.

\section{B. If Benefit-of-the-Bargain Damages Were Truly Compensatory, They Would Be Available for Negligent Misrepresentation}

According to the Second Restatement, benefit-of-the-bargain damages are necessary for fraudulent misrepresentation, "to make the deception of a deliberate defrauder unprofitable to him." "119 This same

116. Id. at 722,725 .

117. The plaintiff had simply made an offer to purchase the property; the seller was obviously under no obligation to sell to the plaintiff. It also does not appear that any enforceable contract existed, as the seller had not accepted the plaintiff's offer to purchase and no written contract existed. See id. at 721-22.

Because the plaintiff had no claim against the seller, the plaintiff sued the third party who ultimately purchased the property, seeking damages based on the profit the plaintiff hoped to make. See id. at 721-22, 725. The most logical argument supporting this theory of recovery would be that the plaintiff was dissuaded from making a second offer on the property. Assuming the plaintiff could prove that the seller would have accepted the offer, the plaintiff could recover consequential damages based on the lost opportunity to purchase the property. To be eligible for these damages, the plaintiff would need to show the existence of the opportunity to a reasonable certainty. KEETON ET AL., supra note 68, § 110, at 767 ("Consequential damages must be established with reasonable certainty, and must not be speculative or contingent...."); see also Leftwich, 521 S.E.2d at 724. But the facts of the case do not support this lost-opportunity theory. The plaintiff had no incentive to make a second offer because the seller had not responded, and the appellate court characterized the damages as "loss of the property value" as opposed to loss of the opportunity to purchase property. See Leftwich, 521 S.E.2d at 725.

118. Leftwich, 521 S.E.2d at 725 .

119. RESTATEMENT (SECOND) OF TORTS $\S 552 \mathrm{~B} \mathrm{cmt}$. b (1977). The proper remedy to deprive the defendant of any profits, however, is restitution. See KEETON ET AL., supra note $68, \S 110$, at 765-66 ("Since the purpose [of restitution] is not to compensate the plaintiff's loss, but to restore what the defendant has received, the courts look to the inequity of allowing him to retain it, rather than to the damage which the plaintiff has sustained."). Regardless, the concern that benefit-of-thebargain damages are necessary to ensure that the defendant does not retain any profit makes little sense because out-of-pocket-losses damages would require the defendant to return the profit made in most cases. By definition, out-of-pocket losses are the difference between what the plaintiff paid and what the plaintiff received, which is also the same as the defendant's profit - the difference between what the defendant sold and received in exchange. See supra note 45 and accompanying text. 
sentiment does not apply to negligent misrepresentation, however, where "the defendant has had honest intentions but has merely failed to exercise reasonable care in what he says or does." 120 Thus, in negligent misrepresentation, "the fault of the maker of the misrepresentation is sufficiently less," and benefit-of-the-bargain damages are not available. $^{121}$ If benefit-of-the-bargain damages were actually compensatory, however, they would be available for negligent misrepresentation. The idea that the amount of compensatory damages depends on the defendant's intentions in making the misrepresentation is an anomaly in tort law.

1. From the Injured Party's Perspective, the Damages Caused by Fraudulent Misrepresentation and Negligent Misrepresentation Do Not Differ

Suppose that the defendant represents that a good is worth $\$ 500$, exciting the plaintiff when he agrees to purchase it for $\$ 250$. In reality, the good has a fair market value at the time of the transaction of only $\$ 200$. After the purchase, the plaintiff has a tangible loss of $\$ 50$ - the difference between the $\$ 250$ the plaintiff paid and the value of the good the plaintiff received. The plaintiff is also left with disappointed expectations. He thought that he was making a profit of $\$ 250$ but ended up with a loss of $\$ 50$. The plaintiff's expectation-based damages are $\$ 300$.

Per the majority rule, if the representation was fraudulent, the plaintiff can recover $\$ 300$ in compensatory damages. This $\$ 300$ provides the plaintiff with the benefit of the bargain, mainly the profit he expected to make through the transaction. Again per the majority rule, if the representation was merely negligent, the plaintiff could recover only $\$ 50$ in compensatory damages. This $\$ 50$ covers the plaintiff's out-ofpocket losses - the difference between the price he paid and the actual value of what he received.

But is the plaintiff not in the exact same position after the transaction regardless of whether the defendant's misrepresentation was fraudulent or negligent? Using the example above, the plaintiff is left with a good

\footnotetext{
120. RESTATEMENT (SECOND) OF TORTS $§ 552 \mathrm{~B} \mathrm{cmt} . \mathrm{b}$.

121. See id. $\S 552 \mathrm{cmt}$. a. The difference in liability is due to the distinction between a duty of care and a duty of honesty. Id. The duty of honesty is implicit in every transaction, whereas the duty of care will exist only in certain circumstances. Id. Those certain circumstances include when the defendant has a pecuniary interest in the representation, which is presumed if the defendant gives the representation within his business, profession, or employment. See id. $\S 552 \mathrm{cmts}$. a \& d.
} 
worth only $\$ 200$ after expecting to receive a good worth $\$ 500$. The plaintiff is no worse off because the defendant acted fraudulently instead of negligently. To the contrary, the plaintiff is left in this same position and suffers the exact same injury, including disappointed expectations, regardless of whether the defendant made a fraudulent or negligent misrepresentation. ${ }^{122}$

Even though the plaintiff is left in the same position, the amount of damages necessary to make the plaintiff whole differs based on whether the defendant knew of the falsity or was negligent concerning the falsity. The unavailability of benefit-of-the-bargain damages for negligent misrepresentation shows that benefit-of-the-bargain damages have little to do with compensating the plaintiff for the injury suffered.

\section{The Amount of Compensatory Damages Recoverable for Other Torts Does Not Vary Based on the Defendant's Mindset}

The amount of compensatory damages in tort law is based on the injury or damage that the plaintiff suffered. ${ }^{123}$ Suppose that the plaintiff is physically injured as a result of the defendant's conduct. Regardless of whether the plaintiff sues the defendant for battery or negligence, the amount of compensatory damages is the same. ${ }^{124}$ The same holds true for property damages. Regardless of whether the plaintiff sues for trespass to chattels or negligence, a successful plaintiff should recover the same amount of compensatory or actual damages. ${ }^{125}$

The same does not hold true, however, for misrepresentation torts, where, under the majority rule, the amount of compensatory damages

122. The Second Restatement claims that the limited liability in negligence "promotes the important social policy of encouraging the flow of commercial information upon which the operation of the economy rests." Id. $\S 552 \mathrm{cmt}$. a. Liability is not limited for fraudulent misrepresentation because "no interest of society is served by promoting the flow of information not genuinely believed by its maker to be true." Id. This marks a departure from the First Restatement's distinction based on whether the fraudulent misrepresentation occurred within a business transaction, within which the vigilance against fraud should be relaxed because businesses do not owe any duty to be completely frank in their dealings. See discussion supra note 57.

Regardless, if tort law truly wants to encourage due diligence and the flow of accurate commercial information, courts should allow the recovery of benefit-of-the-bargain damages for negligent misrepresentation. False representations cause damage because of their falsity. Making benefit-of-the-bargain damages available for negligent misrepresentation would encourage greater diligence and ensure accuracy in commercial dealings.

123. See generally supra notes 22-24 and accompanying text.

124. These damages will likely include lost wages, medical expenses, and pain and suffering. 2 DoBBS, supra note 7, § 8.1(1), at 357.

125. See 1 DoBBS, supra note 7, § 5.13(1), at 836-37 (explaining that the general damages of market value typically apply to both scenarios). 
recoverable for misrepresentation differs based on whether the claim is fraud or negligence. If the defendant was merely negligent, the plaintiff can only recover his out-of-pocket losses. ${ }^{126}$ The defendant's conduct is irrelevant in this measure. If the defendant acted fraudulently, however, the plaintiff can recover the benefit of the bargain. The defendant's conduct controls this measure of damages.

Thus, the amount of damages necessary to make a plaintiff whole after a misrepresentation depends not on the nature or extent of the plaintiff's injury but instead on the defendant's culpability. Is a fraudulent misrepresentation so reprehensible that it qualifies for a special rule of damages? Surely, the defendant committing purposeful battery (and causing physical injury) acts reprehensibly, but the plaintiff will not receive any extra compensation for that reprehensibility. There is nothing special about fraudulent misrepresentation to justify a special measure of damages. As courts have observed, the "law fixing the measure of damages for tort is based upon the proposition that compensatory damages should be, and in the case of every other tort known to the law [except fraudulent misrepresentation] are, measured by the result or effect of the tort rather than by the tort itself."

126. 2 DoBBS, supra note $7, \S 9.2(2)$, at 554 .

127. Hallen v. Martin, 167 N.W. 314, 323 (S.D. 1918) (Whiting \& Gates, JJ., dissenting). The dissenting opinion in Hallen eloquently discusses that the benefit-of-the-bargain measure of damages for fraudulent misrepresentation is inconsistent with the measure of damages for all other torts:

[I]t is clear that the "majority" rule is founded upon the assumption, that compensatory damages should be measured by the tort itself - by the false representations; that the greater, the more numerous, the representations, in other words, the more heinous the tort, the greater should be the recovery, and this regardless of the results that flow from the representations. ... It is because of this very fundamental error - this very fact that the "majority" rule has, as to this one peculiar tort, disregarded the rule governing damages for every other known tort- that the "majority" rule stands upon a basis both unsound and exceptional. Attempt to apply to any other tort the rule that there is a direct relation between the amount of compensatory damages that should be recovered and the number, the moral gravity, or the enormity of the torts committed, and see to what result one would arrive. It is true that there must be a tort, else there is no wrong upon which to base recovery; but unless the tort, as a cause, produces an effect detrimental to the innocent person, there can be no recoverable damages; and whenever compensatory damages are recoverable they should always be measured by the effect produced by the tort, and not by the tort itself. We cannot logically measure damages by the cause in the case of one tort, and by the effect in the case of some other tort, but, if we do, we should at least concede that we are using two rules for such measurements.

Id. (emphasis added); see also Barton, supra note 94, at 1825 ("Unlike other tort claims that seek to compensate the injured party, fraud seeks to remedy the wrong by restoring to the plaintiff what the defendant has taken wrongfully."). 


\section{THE AVAILABILITY OF COMPENSATORY BENEFIT-OF-THE-BARGAIN DAMAGES IN CONTRACT DOES NOT JUSTIFY THEIR AVAILABILITY IN TORT}

Courts likely are comfortable awarding benefit-of-the-bargain damages as compensatory damages for fraudulent misrepresentation because they are available as compensatory damages for breach of contract. ${ }^{128}$ The additional "allegation of intent to deceive should certainly not decrease" the potential recovery. ${ }^{129}$ And "it is difficult to see why identical damages do not flow from false representations of facts which would flow from false warranties of the identical facts."

A breach of contract and a fraudulent misrepresentation, however, are different wrongs, meaning that the resulting damages may differ. Unlike in contract law, the parties' expectations do not control liability or the scope of compensatory remedies in tort. Further, the various justifications for awarding benefit-of-the-bargain damages for breach of contract do not support awarding the same damages for fraudulent misrepresentation.

\section{A. The Breach of Contract, Not the Fraudulent Misrepresentation, \\ Causes the Loss of the Bargain}

Within the breach-of-contract context, benefit-of-the-bargain damages monetarily mandate contract performance. By analogy, perhaps compensatory damages for fraudulent misrepresentation should have a similar effect. Just as benefit-of-the-bargain damages effect contract performance in contract, benefit-of-the-bargain damages should make the defendant's misrepresentation true in tort. ${ }^{131}$ Under this view, the falsity of the representation is the tort. ${ }^{132}$ Compensatory damages then remedy

128. See Charles T. McCormick, Handbook on the Law of Damages $\S 121$, at 451-52 (1935) (explaining that awarding benefit-of-the-bargain damages for fraudulent misrepresentation is consistent with the measure of damages awarded for breach of contract, making it easier to apply benefit-of-the-bargain damages in fraud claims); see also Monserud, supra note 35, at 483 (explaining the common sentiment in the case law that "deliberate fraud (deceit) must not yield lesser damages than "mere breach of warranty"').

129. KEETON ET AL., supra note $68, \S 110$, at 768.

130. Hallen, 167 N.W. at 319 (Smith, J., concurring).

131. See id. ("The [benefit-of-the-bargain damages] rule awards the injured party an amount which makes good the representations.").

132. See id. at 318 ("The essential wrong was in the falsity of the representations relating to the value, or relating to the value or qualities, of the thing which the injured party was induced to accept instead of that which he was entitled to receive."). Reframing the tort in this way enables avoidance of a common sense application of compensatory damages. The purpose of compensatory damages is 
that falsity by awarding the amount necessary to make the representation true. $^{133}$

Still, making the representation true could mean two things - either we pretend the defendant truthfully stated the actual value of the good or the good was actually worth the amount that the defendant represented. In the former possibility, the likely result is that the bargain would not have occurred. If the purchase price was $\$ 250$ and the defendant truthfully represented that the good was worth only $\$ 200$, the plaintiff would not agree to the transaction. ${ }^{134}$ If no bargain would occur, the plaintiff could not have any benefit-of-the-bargain damages.

The second possibility is that we pretend that the good is actually worth the amount the defendant represented. If the representation that the good is worth $\$ 500$ was actually true and the plaintiff actually entered into a contract to purchase the good, the plaintiff would have expected a profit of $\$ 250$. In this possibility, "if the representations had been true instead of false, the injured party would have received property 'answering to the representations made.", 135 Therefore, "[t]he difference between [the good's] value as represented and its actual value...

to put the plaintiff back to the same place he was before the tort occurred-as if the misrepresentation never occurred. See supra note 22 and accompanying text. If the tort is the falsity of the representation, however, damages presume that the representation still occurred and that the compensatory damages should put the plaintiff in the same position as if the representation had been true.

133. Conceptually, difficulty arises when attempting to separate the falsity of the representation from the representation itself. In fraudulent misrepresentation, the representation was false when made and no possibility ever existed that the representation was true. Why then should the measure of damages pretend that the representation was true? This is unlike a breach of contract where the defendant intended to perform when he entered into the contract but later chose to not perform. A possibility of performance existed in the breach-of-contract context, but no possibility of truth ever existed in the fraudulent misrepresentation context.

Additionally, the idea of making the representation true within the measure of damages is inconsistent with the measure of damages for other torts. Damages for battery do not presume that the contact still occurred and that the harmfulness of the contact is the tort. Further, damages for battery do not compensate the plaintiff based on the benefits the plaintiff would have experienced had the contact been beneficial instead of harmful. For further discussion of how the benefit-of-thebargain measure of damages for fraudulent misrepresentation differs from the measure of damages applicable to other torts, see supra Part V.B.

Lastly, if the falsity of the misrepresentation is the tort, this is a further basis for arguing that liability for negligent misrepresentation - also involving a false representation - should also award benefit-of-the-bargain damages. See generally supra Part V.B (arguing that if benefit-of-the-bargain damages were truly compensatory, they would be available for negligent misrepresentation).

134. See Hallen, 167 N.W. at 320 (Whiting \& Gates, JJ., dissenting) (“An action for damages for deceit in all cases, whether those involving sales or exchanges of property or whatsoever the nature of the case, must be based upon the premise that, if it had not been for the deceit, there would have been no purchase or exchange whatsoever.").

135. Id. at 318 . 
measures the loss or damage proximately caused by the deceit,"136 meaning that damages should total $\$ 250$.

This second possibility blurs the distinction between the fraudulent misrepresentation and the later contract to purchase the good at issue in the misrepresentation - it assumes that the misrepresentation itself causes both the expected profit and receipt of the good. That the representation alone cannot create the expectation is apparent once the representation is separated from the transaction. The representation is that a good is worth $\$ 500$ and nothing more. The representation invites reliance, but it does not bind the person making the representation to do anything. ${ }^{137}$ Further, any resulting reliance on the representation cannot cause the plaintiff to expect to purchase the good and make a profit. ${ }^{138}$ Rationally, the plaintiff cannot expect to purchase the good before he actually makes an offer to purchase that the seller accepts. The representation may increase the plaintiff's interest in the good, but an expected profit is only possible if the plaintiff and the defendant enter into a contract.

The plaintiff would likely argue that he relied on that representation in agreeing to purchase the good. But if the representation were true, the plaintiff still would have no damages without the defendant's contractual agreement to sell the good. Without the agreed-upon purchase price in the contract, the plaintiff still could not expect a specific profit. The contract is necessary before the plaintiff can expect any profit. ${ }^{139}$

136. Id.

137. See Charles Fried, Contract as Promise: A Theory of Contractual Obligation 11 (1981) (rejecting the argument that the promisor is bound to pay expectation damages in contract simply because the promise invites the promisee to rely on the promise). Fried explains:

Perhaps the statement of intention in promising is binding because we not only foresee reliance, we invite it: We intend the promisee to rely on the promise. Yet even this will not do. If I invite reliance on my stated intention, then that is all I invite.... [I am not] bound as I would be had I promised.

A promise invokes trust in my future actions, not merely in my present sincerity. We need to isolate an additional element, over and above benefit, reliance, and the communication of intention. That additional element must commit me, and commit me to more than the truth of some statement.

Id.

138. To recover for misrepresentation, the plaintiff has to prove that his reliance on the representation was reasonable. See infra note 180 and accompanying text. Within this required element, the plaintiff should also have to prove that his understanding of the representation was reasonable. If the defendant merely represents the value of a good, the plaintiff cannot be led to believe that he would thus automatically be able to purchase the good and make a profit on it.

139. See, e.g., Goodrich \& Pennington Mortg. Fund, Inc. v. J.R. Woolard, Inc., 101 P.3d 792, 796 (Nev. 2004) (explaining that benefit-of-the-bargain damages put the parties in the "same position as if the contract and representations had been fully performed" (quoting Lightning Litho, Inc. v. Danka Indus., 776 N.E.2d 1238, 1242 (Ind. Ct. App. 2002) (emphasis added))). 
Similarly, the receipt of the expected profit is only possible if the plaintiff and the defendant enter into a contract. The plaintiff's "right to receive the kind of thing contracted for was fixed by the contract" and not the misrepresentation. ${ }^{140}$ The idea that "if the representations had been true instead of false, the injured party would have received property 'answering to the representations made" ${ }^{\prime 141}$ is simply incorrect. Even if the representation was true, the injured party would have received the property only if he had a contractual claim to it. ${ }^{142}$

The only point at which the plaintiff truly has an expectation of profit or other benefit is when the plaintiff and the defendant have entered into a contract regarding the good at issue, even if the good's value is the subject of a misrepresentation. ${ }^{143}$ The misrepresentation of value does not create any expectation and the compensatory damages for a fraudulent misrepresentation should not fulfill any lost expectation. If the plaintiff wants to recover the expected benefit based on the agreedupon purchase price, the plaintiff should sue for breach of contract.

\section{B. Expectations Do Not Control the Duty and the Amount of Damages in Tort Law}

Even if the misrepresentation could cause an expectation, that expectation does not have the same relevance in tort law that it does in

140. Hallen, 167 N.W. at 318 (Smith, J., concurring). The concurrence believed that "the injured party was entitled to receive that which he was induced to believe he was receiving, and which he would have received under an honest contract." Id. The Hallen majority used the same analysis to conclude that the plaintiff was entitled to benefit-of-the-bargain damages because of the misrepresentation. See id. ("That he did not receive [the thing contracted for] was due to the deceit which wrongfully induced him to believe he was receiving it when he was not in fact receiving it."). But the Hallen court's conclusion does not follow from the analysis. The court admitted that the plaintiff's right to receive existed only because of the contract. Thus, the misrepresentation did not entitle the plaintiff to receipt, and its falsity could thus have not caused the plaintiff's nonreceipt.

141. Id. at 318 .

142. Similarly, the idea that benefit-of-the-bargain damages for fraudulent misrepresentation will provide the plaintiff "any economic gains he would have had if the representations had been correct" is flawed. 2 DOBBS, supra note $7, \S 9.2(1)$, at 551. If the representations were indeed correct, the plaintiff would not necessarily achieve any economic gains; the plaintiff's contractual entitlement to the good is a necessary part of his achieving economic gains.

143. "[T]he courts have restricted recovery to those losses which might be expected to follow from the fraud and from events that are reasonably foreseeable." KEETON ET AL., supra note 68, $\S 110$, at 767 . The formation of a contract to purchase the good at issue in the misrepresentation is an event expected to follow from the defendant's fraudulent misrepresentation. Still, any damages recoverable for fraudulent misrepresentation are limited by the purposes of tort law. See supra Part II.B. Thus, even if a contract and the breach of the contract are reasonably foreseeable after a fraudulent misrepresentation, tort law does not allow compensation of a lost expectation because such compensation would award the plaintiff the value of a good that the plaintiff did not own (or have a contractual right to) before the misrepresentation occurred. 
contract law. An award of benefit-of-the-bargain damages is appropriate for breach of contract but not for fraudulent misrepresentation.

Within a contract, the parties' promises define the duties owed and the expectations resulting from those duties. Those same expectations define the amount of compensatory damages: "[C]ompensation is defined by the parties' own promises and the risks they undertook." For instance, the defendant may have agreed to dig the plaintiff a well for a certain price to enable plaintiff to get water to his cattle. The amount of compensatory damages is then based on the risk that the defendant agreed to protect against, mainly the risk that the cattle would not have water. $^{145}$ The recoverable expectation-based compensatory damages in contract would monetarily put the plaintiff in the same position as if the well provided his cattle with water. This measure of damages is consistent with the purpose of compensatory damages in contract law: to put the nonbreaching plaintiff in the same position as if the breach had not occurred. ${ }^{146}$

The parties' expectations play a very different role in tort law. External societal law determines whether a tort-based duty exists. ${ }^{147}$ For instance, tort law imposes on an attorney a duty to use reasonable care in representing a client. ${ }^{148}$ The client may also expect the attorney to exercise care, but the client's expectation alone does not give rise to the duty. The client's expectation similarly does not control the amount of compensatory damages. Instead, external societal law declares that the amount of compensatory damages for legal malpractice is "the amount of loss actually sustained by the [client]" as a result of the lawyer's conduct. ${ }^{149}$

\footnotetext{
144. 3 DoBBS, supra note $7, \S 12.1(1)$, at 6 .

145. See id.

146. See supra Part II.A.1.

147. See Jody Kraus, The Correspondence of Contract and Promise, 109 COLUM. L. REV. 1603, 1613-15 (2009) (distinguishing between tort law's enforcement of moral duties and contract law's enforcement of voluntarily undertaken moral obligations).

148. See, e.g., Wettanen v. Cowper, 749 P.2d 362, 364 (Alaska 1988); TJD Dissolution Corp. v. Savoie Supply Co., 460 N.W.2d 59, 62 (Minn. Ct. App. 1990).

149. See Black v. Shultz, 530 F.3d 702, 709 (8th Cir. 2008) (quoting Bellino v. McGrath North Mullin \& Kratz, PC LLO, 738 N.W.2d 434, 445 (Neb. 2007)). Although it may seem it, this is not an expectation-based measure of damage. The client may have expected to obtain a judgment, but the client had a viable claim, which has monetary worth. If the client is unable to recover damages for the claim because of the attorney's malpractice, the client has an actual loss as opposed to a mere disappointed expectation.

Certain torts do compensate for a lost expectation, but only if the expectation arose due to a source other than the defendant. These torts include intentional interference with contract or business expectancy. The measure of damages recoverable for either of these torts likely includes loss of the benefit of the contract that the plaintiff had with a nonparty. See RestatemENT (SECOND) OF TORTS § 774A(1)(a) (1979) (providing for damages based on "the pecuniary loss of the
} 
Consistent with the rest of tort law, the party's expectation does not control the existence of a duty in fraudulent misrepresentation. Instead, tort law imposes an "unequivocal" duty of honesty when making representations. $^{150}$ Obviously, a plaintiff may also expect a defendant to be honest when providing representations, but the duty is "unequivocal" regardless of the expectation. ${ }^{151}$ Because the party's expectation does not control the existence of the duty, the party's expectation also should not control the amount of compensatory damages for fraudulent misrepresentation. ${ }^{152}$ Instead, the amount of compensatory damages should be based on the actual loss. This actual loss measure is not only consistent with the measure of compensatory damages in other torts, it "is [also] more consistent with the purpose of tort remedies, which is to compensate the plaintiff for a loss sustained, rather than to give him the benefit of any contract bargain." "153

Moreover, basing compensatory damages on expectations is consistent with both parties' expectations in contract, but not in tort. The effect of awarding expectation-based compensatory damages for breach of contract is that both parties perform the obligations they agreed and expected to perform. ${ }^{154}$ In tort, however, benefit-of-the-bargain damages do not cause both parties to perform their expected obligations. ${ }^{155}$ This is

benefits of the contract or the prospective relation"); KEETON ET AL., supra note 68, § 129, at 1003 (observing that states have adopted one of three different measures of damages: a contract measure, a measure similar to that recoverable for negligence, or a measure similar to that recoverable for an intentional tort). Similarly, damages for lost future wages are based on the plaintiff's expectation of receiving wages in the future. The plaintiff's expectation of a benefit from a contract or future wages exists before and independent of the defendant's tortious conduct. If the source of the expectation is independent of the defendant and the plaintiff can prove the existence of that expectation, its loss should be compensated in tort.

In cases of fraudulent misrepresentation, however, the defendant's misrepresentation does not create an expectation. See supra Part VI.A. Even if it did, the loss of the expectation would not be compensable in tort. Instead, that lost expectation is compensable through contract and contractual warranty claims. If the plaintiff wants to ensure his ability to sue based on any representations, he should negotiate for contractual warranties.

150. RESTATEMENT (SECOND) OF TORTS $\S 552 \mathrm{cmt}$. a (1977).

151. Id. The Second Restatement discusses that "any user of commercial information may reasonably expect the observance of this [honesty] standard," but the duty is "unequivocal" regardless of the existence of the expectation. Id.

152. Further, if there were some special justification for an award of benefit-of-the-bargain damages for the expectation that the defendant created through a fraudulent misrepresentation, that same justification should support an award of benefit-of-the-bargain damages for a claim of negligent misrepresentation. In both claims, the defendant creates an expectation through a false representation. See supra Part V.B.

153. KeETON ET AL., supra note $68, \S 110$, at 768 ; see also supra Part II.B.

154. See supra Part II.A.1.

155. But see Kendrick v. Ryus, 123 S.W. 937, 940 (Mo. 1909) (concluding that benefit-of-thebargain damages are a reasonable measure of damages because they give effect to both parties' expectations). The Kendrick court analyzed as follows: 
because a representation regarding future actions or constituting a promise to perform is an actionable misrepresentation only if the defendant has no intent or expectation to perform at the time he makes the representation. ${ }^{156}$ The defendant never intended for the

But for the fact that the purchaser thought he was getting a bargain he might not have made the contract at all. If by fraud and deceit he is induced to believe that he is contracting for a benefit or a bargain, and not merely swapping dollars, why should not the benefits of the bargain be an element in the measure of damages in an action for fraud and deceit? Such benefit would be a matter fully contemplated by both parties. By the purchaser, because, as a rule, trades are not made for the purpose of merely exchanging dollars. By the seller, because he would not falsely represent the character of the property save and except to induce the purchaser to believe that he was procuring a benefit of bargain. Being, therefore, a matter fully contemplated by both parties, we are impressed with the reasonableness of the rule which allows the "benefits of the bargain" as a proper element of damages in cases of fraud and deceit.

Id. This analysis looks only to whether the seller expected the purchaser to perform and not whether the seller expected himself to perform. Even if the purchaser expected the seller to perform, the seller never expected to perform because the seller was aware of the falsity of representation when he made it.

156. See, e.g., CADCO, Inc. v. Fleetwood Enters., 220 S.W.3d 426, 436 (Mo. Ct. App. 2007) ("It is well-settled that an unkept promise does not constitute actionable fraud unless the promise is accompanied by the defendant's present intent not to perform, which constitutes a misrepresentation of a present state of mind, itself an existent fact.").

Remarkably, the Second Restatement embraces the idea that the plaintiff can pursue a fraudulent misrepresentation and receive benefit-of-the-bargain damages even when the underlying bargain is unenforceable:

The intention to perform the agreement may be expressed but it is normally merely to be implied from the making of the agreement. Since a promise necessarily carries with it the implied assertion of an intention to perform it follows that a promise made without such an intention is fraudulent and actionable in deceit under the rule stated in $\S 525$. This is true whether or not the promise is enforceable as a contract. If it is enforceable, the person misled by the representation has a cause of action in tort as an alternative at least, and perhaps in some instances in addition to his cause of action on the contract. If the agreement is not enforceable as a contract, as when it is without consideration, the recipient still has, as his only remedy, the action in deceit under the rule stated in $\S 525$. The same is true when the agreement is oral and made unenforceable by the statute of frauds, or when it is unprovable and so unenforceable under the parol evidence rule. The tort action may have other advantages, as when it is subject to a longer statute of limitations. In all of these cases, it is immaterial to the tort liability that the damages recoverable are identical with, or substantially the same as, those which could have been recovered in an action of contract if the promise were enforceable.

RESTATEMENT (SECOND) OF TORTS $\S 530 \mathrm{cmt}$. c. Although this Restatement provision appears to allow fraudulent misrepresentation claims to proceed even when the underlying bargain is unenforceable, it is not clear that the plaintiff would be able to do so. The commentary to section 549 , which provides for benefit-of-the-bargain damages, seems to assume that the underlying bargain between the plaintiff and the defendant must be enforceable. See id. § 549(2) ("The recipient of a fraudulent misrepresentation in a business transaction is also entitled to recover additional damages sufficient to give him the benefit of his contract with the maker ...." (emphasis added)). The commentary states: "When the plaintiff has not entered into any transaction with the defendant but has suffered his pecuniary loss through reliance upon the misrepresentation in dealing with a third person, [out-of-pocket losses is] the rule[] that must of necessity be applied." Id. § 549 cmt. g; see also KEETON ET AL., supra note 68, § 110, at 768 (stating that out-of-pocket losses "must of necessity be adopted where the defendant is a third party who has made no contract with the 
representation to be true or to perform, but awarding benefit-of-thebargain damages for the misrepresentation requires him to do so. ${ }^{157}$ The contract law sentiment that benefit-of-the-bargain damages merely require parties to carry out their agreed-upon, expected performances does not apply equally to the tort of fraudulent misrepresentation.

\section{Various Justifications for Compensatory Benefit-of-the-Bargain Damages in Contract Law Do Not Apply to Tort Law}

Even in contract law, commentators have questioned the appropriateness of measuring compensatory damages based on the benefit of the bargain. ${ }^{158}$ Commentators have created various justifications for the measure of damages. Regardless of the wisdom of the justifications, they do not support an award of benefit-of-the-bargainbased compensatory damages for fraudulent misrepresentation. ${ }^{159}$

\section{Any Alleged Expectation Lacks Present Cash Value}

One justification for the compensation of expectancies for breach of contract is that, although contract performance will occur in the future, that future performance has present value.

Expectations of future values become ... present values. In a society in which credit has become a significant and pervasive institution, it is inevitable that the expectancy created by an enforceable promise should be regarded as a kind of property, and breach of the promise as an injury to that property.

plaintiff').

157. Proponents of benefit-of-the-bargain damages would argue that the defendant's lack of intent should not excuse him. This is a common argument; the wrongdoer should not be subject to lesser damages for his fraud than for his breach of contract. This argument, however, does not necessarily mandate that benefit-of-the-bargain damages be available as compensatory damages.

158. See Farnsworth, supra note 6, at 1148 (criticizing benefit-of-the-bargain damages as a "queer kind of "compensation" because "it gives the promisee something he never had" (quoting Fuller \& Perdue, supra note 12, at 53)).

159. If any of the justifications supported an award of benefit-of-the-bargain damages for fraudulent misrepresentations, the justifications would also support an award of benefit-of-thebargain damages for negligent misrepresentation.

160. Fuller \& Perdue, supra note 12, at 59. Fuller and Perdue actually rejected this justification because it is a circular argument - expectancies have present values because the law enforces them. Id. If the present value of expectancies is due to the enforceability of the expectancy, expectancies allegedly created by fraudulent misrepresentation would also have present value. Regardless, commentators have rejected any claim that the circularity defeats the present value of contractual expectations:

Even if it were a fact that contracts (i.e., enforceable promises) have present value only because the law enforces them (i.e., because the law awards expectation damages), that 


\section{a. Present Cash Value Depends on the Existence of Sufficient} Consideration

A contractual expectation itself is the plaintiff's property; the property interest being a credit or entitlement to fulfillment of the expectation. ${ }^{161}$ The plaintiff, however, must own or have a right to this credit. An enforceable right to the fulfillment of the expectation exists only if the contract is supported by sufficient consideration. ${ }^{162}$ If the plaintiff has provided sufficient consideration, "the promisee has formed an attitude of expectancy such that a breach of the promise causes him to feel that he has been 'deprived' of something which was 'his."'163 But if the plaintiff has not provided sufficient consideration to support the contract, it's not as easy to conclude that the plaintiff has been deprived of something that was "his." To the contrary, the expectation is unenforceable and has no present value.

In the typical fraudulent misrepresentation claim, the plaintiff does not "own" the alleged expectation because he has not given any consideration. Unlike the situation where a buyer has agreed to purchase a good from the seller - a contract supported by consideration-a recipient of a fraudulent misrepresentation has not agreed to do anything in exchange for the misrepresentation. To ultimately recover on the fraudulent misrepresentation, the plaintiff will have to establish reliance on the misrepresentation to his detriment. But reliance to his detriment is not the same thing as consideration, as in actually paying for the expectation. In the commercial setting, property is obtained through

would not prevent the fact that the credit system treats contracts as property from being an institutional justification for the expectation measure. For if the credit system requires the use of the expectation measure to function effectively, as Fuller and Perdue acknowledged it does, this is all that matters for justification purposes. It is irrelevant whether the credit system or the expectation measure came first historically.

W. David Slawson, Why Expectation Damages for Breach of Contract Must Be the Norm: A Refutation of the Fuller and Perdue “Three Interests" Thesis, 81 NEB. L. REV. 839, 859 (2003).

161. See infra notes 168-70 and accompanying text.

162. Promises within a contract are enforceable only if supported by sufficient consideration. See generally RESTATEMENT (SECOND) OF CONTRACTS $§ 71$ (1981) (discussing the performance or promise necessary to constitute consideration). The Second Restatement of Contracts concludes that in cases of promissory estoppel—such as an enforceable contract despite the lack of sufficient consideration-benefit-of-the-bargain damages may not be appropriate. Id. $\S 90 \mathrm{cmt}$. d ("[R]elief may sometimes be limited to restitution or to damages or specific relief measured by the extent of the promisee's reliance rather than by the terms of the promise."). But see W. David Slawson, The Role of Reliance in Contract Damages, 76 CORNELL L. REV. 197, 236-37 (1990) (arguing that courts refuse to use a measure of damages other than benefit-of-the-bargain in promissory estoppel claims).

163. Fuller \& Perdue, supra note 12 , at 57. 
purchase. Buyers cannot skirt the purchase requirement through mere reliance.

Reliance also cannot create an enforceable property right. ${ }^{164}$ To base a property interest on an expectation, "a person clearly must have more than an abstract need or desire for" the expectation, and the expectation cannot be merely unilateral. ${ }^{165}$ Instead, the plaintiff would need to show "a legitimate claim of entitlement" to the expectation. ${ }^{166}$ Without some consideration, the plaintiff lacks a legitimate claim of entitlement to the expectation allegedly created by a fraudulent misrepresentation.

\section{b. Present Cash Value Depends on the Assignability of the Expectation}

Another reason that contractually created expectations constitute property is that contractual rights are assignable. ${ }^{167}$ "If something can be bought and sold, it is property .... As such, any contract right that can be assigned is property ... and, as a rule, the law allows any contract right to be assigned."168 Assignable contract rights include the right to performance of the contract - fulfillment of the assigned expectation. ${ }^{169}$ The expectation measure is thus "the value of a contract right in the market economy," based on the valuation of the expectation resulting from the contract right. ${ }^{170}$

Unlike a contractually created expectation, any expectation allegedly resulting from a fraudulent misrepresentation cannot be assigned. A

164. According to Fuller and Perdue, "[t]hat the promisee had not 'used' the property which the promise represents (had not relied on the promise) is ... immaterial" to the present value of a contractual expectation. Id. at 59 .

165. Bd. of Regents of State Colls. v. Roth, 408 U.S. 564, 577 (1972).

166. Id.

167. Slawson, supra note 160, at 861 ("It was not, as Fuller and Perdue maintained, the general enforceability of promises that made contract rights property, rather... it was the general assignability of contract rights." (footnotes omitted)). Slawson admits that an unassignable contract right can still constitute a property interest. See id. at 846 n.22. These contractual rights in employment, however, are property interests because of the employee's "legitimate claim of entitlement" to employment due to the contract's terms. See Roth, 408 U.S. at 577.

168. Slawson, supra note 160 , at 845 .

169. Slawson characterizes the benefit-of-the-bargain measure of damages as "the value of a contract right in a market economy." $I d$. at 849 . A plaintiff in a fraudulent misrepresentation claim should not be compensated based on "the value of a contract right in a market economy." This measure of compensation is even more inappropriate in tort law if the lost contract right is unenforceable.

170. Id. Slawson argues that even if the law did not enforce contractual expectations, the expectation would still have present value due to "[a]ll sorts of other factors-honor, reputation, reciprocity ('I will keep my promises to you if you keep yours to me.'), and simple honesty, for example." Id. at 860. Honor, reputation, and honesty may also create some present value for an expectation allegedly created by a fraudulent misrepresentation. Reciprocity, however, would not apply to fraudulent misrepresentations because of the lack of consideration. 
misrepresentation does not create any tangible "right" to the fulfilled expectation that could be assigned. ${ }^{171}$ A recipient of a misrepresentation, like that a good is worth $\$ 500$, cannot assign the receipt to another. Any expectation based on the misrepresentation thus cannot have present value. ${ }^{172}$

\section{Tort Law Does Not Contemplate Efficient Breaches of Contract}

Another justification for benefit-of-the-bargain damages is that it is the only measure of damages to ensure efficient breaches of contract. ${ }^{173}$ Contract law encourages parties to breach contracts when the breach would be economically efficient. ${ }^{174}$ Without expectation-based damages, a party would not be able to determine the economic efficiency of breaching. ${ }^{175}$

The concept of efficient breach does not apply to misrepresentation torts. In an efficient breach, a defendant initially agrees to the contract but later decides to breach because of the economic efficiency. When a defendant makes a fraudulent misrepresentation, however, the representation is false at the time of the tort-either the statement of fact is false, or, if the representation is promissory, the defendant lacks the intent to perform at the time. ${ }^{176}$ Similarly, the defendant must have the intent to deceive at the time of making the misrepresentation. ${ }^{177}$ Because of the falsity of the representation and the fraudulent intent at the time of

171. Some nonassignable contract rights, including a right to employment, are property with present value even though the right is not assignable. Still, those expectations are supported by consideration. See supra notes 164-66 and accompanying text (explaining that reliance is insufficient to create a property right).

172. Generally, tort claims are not assignable if they are "personal" in nature. TMJ Haw., Inc. v. Nippon Trust Bank, 153 P.3d 444, 452 (Haw. 2007). Personal injury claims or claims based on emotional distress are not assignable. See id. Tort claims for damage to real or personal property are assignable, especially when the assignee has purchased the damaged property. Id. There is a difference between assigning an entire claim and assigning an expectation allegedly resulting from a misrepresentation. When the claim is assigned, damage has already occurred; so property is already damaged and the assignee can recover the property damage. If the plaintiff has merely heard the misrepresentation, however, the plaintiff has nothing to assign.

173. See Slawson, supra note 160 , at 855 ("Only the expectation measure provides the right incentives for making breaches Pareto efficient, [meaning that] this measure leaves the party who did not breach neither worse nor better off than if the contract had been performed.").

174. See Seana Valentine Shiffrin, The Divergence of Contract and Promise, 120 Harv. L. Rev. 708, 730-33 (2007).

175. But see Slawson, supra note 160 , at 855 (arguing that efficient breaches do not justify benefit-of-the-bargain damages "because most breaches result from human weakness or miscalculation - carelessness, mistake, laziness, scheduling too many jobs to do at the same time, etc.- -rather than from a conscious decision to breach").

176. See Restatement (SECOND) OF TORTS $\S 525 \mathrm{cmts}$. d \& f (1977).

177. See id. §525. 
the representation, the concept of efficient breach cannot apply to misrepresentation torts. Obviously then, the need to enable efficient breaches could not justify an award of benefit-of-the-bargain damages for fraudulent misrepresentation.

\section{Tort Law Has No Interest in Encouraging Commercial Activity}

Even though the damages in contract give the plaintiff something he did not have before the contract was made, benefit-of-the-bargain damages are still justified and beneficial because they encourage people to make contracts. ${ }^{178}$ The purposes of tort law do not include encouraging people to enter into contracts. ${ }^{179}$ Thus, this effect of benefitof-the-bargain damages does not justify the availability of such damages for fraudulent misrepresentation.

One could argue that the tort equivalent of encouraging commercial activity is encouraging reliance; thus, benefit-of-the-bargain damages should be available because such damages would encourage people to rely on representations. But tort law does not want people to blindly rely on representations. In fact, tort law discourages blind reliance; before a plaintiff can recover damages for fraudulent misrepresentation, he must demonstrate that his reliance on the representation was reasonable or justifiable. ${ }^{180}$ Encouraging people to make contracts has no parallel in tort law to justify an award of benefit-of-the-bargain damages for fraudulent misrepresentation.

178. See Farnsworth, supra note 6, at 1148 (criticizing benefit-of-the-bargain damages as a "queer kind of "compensation" because "it gives the promisee something he never had" but justifying the existence of benefit-of-the-bargain damages to encourage people to make contracts (quoting Fuller \& Perdue, supra note 12, at 53)); see also Slawson, supra note 160, at 845 ("Although many contracts presumably would be made and kept even if the law did not enforce them, the law's enforcing them encourages the making of more of them and increases the value of those that are made by providing an important additional assurance that they will be kept.").

179. See supra Part II.B.

180. See RESTATEMENT (SECOND) OF TORTS $\S 525$. Tort law also sometimes obligates the plaintiff to investigate the subject of the representations before the reliance can be reasonable. See id. $\S 541 \mathrm{cmt}$. a ("Although the recipient of a fraudulent misrepresentation is not barred from recovery because he could have discovered its falsity if he had shown his distrust of the maker's honesty by investigating its truth, he is nonetheless required to use his senses, and cannot recover if he blindly relies upon a misrepresentation the falsity of which would be patent to him if he had utilized his opportunity to make a cursory examination or investigation."); see also Abu Dhabi Commercial Bank v. Morgan Stanley \& Co., 651 F. Supp. 2d 155, 172 (S.D.N.Y. 2009) ("Reasonable reliance entails a duty to investigate the legitimacy of an investment opportunity where the plaintiff was placed on guard or practically faced with the facts." (quoting Crigger v. Fahnestock \& Co., 443 F.3d 230, 234 (2d Cir. 2006))). 
4. Any Morality-Based Justification Would Mandate Punitive Damages in Tort

The promise principle recognizes a moral obligation to keep promises:

An individual is morally bound to keep his promises because he has intentionally invoked a convention whose function it is to give grounds - moral grounds-for another to expect the promised performance. To renege is to abuse a confidence he was free to invite or not, and which he intentionally did invite. ${ }^{18}$

Commentators repeatedly reject the morality-based promise principle as the justification for benefit-of-the-bargain damages for breach of contract because it conflicts with encouraging efficient breaches of contract, ${ }^{182}$ one of the same reasons why contract law does not impose punitive damages. ${ }^{183}$ If a party owes a moral duty to keep his promise, that party would not be free to breach if the breach is economically efficient. ${ }^{184}$ Commentators also argue that if a moral obligation to maintain promises really exists, it requires more than expectation-based damages; instead, the moral obligation would require specific performance of the contract. ${ }^{185}$

Even if moral grounds do not support the award of benefit-of-thebargain damages for breach of contract, the grounds may support such an award for fraudulent misrepresentation. Unlike in breach of contract, the speaker of a fraudulent misrepresentation acts with an "intent to

181. FRIED, supra note 137 , at 16.

182. See Kraus, supra note 147, at 1606 ("To many, the efficient breach hypothesis suggests that expectation damages actually encourage and thereby endorse breach. So understood, the objection to the expectation damages rule is not merely that it falls short of enforcing the promisor's corresponding moral duty, but that it affirmatively undermines it."); see also id. at 1604 n.3 (listing scholarly articles supporting the efficient breach principle).

183. See supra note 6 and accompanying text.

184. See Shiffrin, supra note 174, at 722 (“[T]ypically, a promisor is morally expected to keep her promise through performance.").

185. See id. at 722-23 ("Contract law, however, diverges from morality in this respect. Contract law's dominant remedy is not specific performance but expectation damages."); see also DORI Kimel, From Promise to CONTRACT: TOWARDS A LiBeral THEORY OF CONTRACT 95-96 (2003); Peter Benson, The Idea of a Public Basis of Justification for Contract, 33 OsGoOdE HALL L.J. 273, 291-93 (1995); T. M. Scanlon, Promises and Contracts, in THE THEORY OF CONTRACT LAW: NEW ESSAYS 86, 92 (Peter Benson ed., 2001). Fried may have advocated expectation damages instead of specific performance because of efficient breaches. Gil Lahav, A Principle of Justified PromiseBreaking and Its Application to Contract Law, 57 N.Y.U. ANN. SURV. AM. LAW 163, 177-78 (2000). 
deceive." 186 The moral imperative to force the fraudulent party to make good on his representation seems even stronger for fraudulent misrepresentation than for breach of contract.

In tort, though, the moral imperative that people should not lie would not justify an award of compensatory benefit-of-the-bargain damages. Compensatory damages are supposed to return the plaintiff to his position before the tort. ${ }^{187}$ Morality mandates relief not because of the plaintiff's changed position or because the plaintiff has some expectation deriving from the promise. This is evident in the fact that morality would require a promisor to keep his promise even if the promisee were dead. $^{188}$

Applied to fraudulent misrepresentation, morality would require the defendant to pay expectation-based damages because the defendant acted immorally when making the fraudulent misrepresentation. In tort, these damages are punitive because they focus on the defendant's conduct. ${ }^{189}$ Even in the contract context the punitive nature of the morality theory is evident: "If one gives great weight to the morality of promise-keeping, [the moral obligation] would support enforcement of penalties."190 Thus, if applicable to fraudulent misrepresentation, morality would mandate an award of punitive, and not compensatory, damages for the defendant's egregious and intentional conduct. ${ }^{191}$

Another reason that morality cannot justify benefit-of-the-bargain damages for fraudulent misrepresentation is that the vast majority of

186. See supra note 129 and accompanying text.

187. See supra Part II.B.

188. See FRIED, supra note 137, at 15 (discussing that any theory that would allow a promisor to not keep his promise just because the promisee is dead is not a moral theory).

189. See infra notes 222-23 and accompanying text.

190. Kenneth C. Kettering, True Sale of Receivables: A Purposive Analysis, 16 AM. BANKR. INST. L. REV. 511, 548 (2008); see also Shiffrin, supra note 174, at 710, 726-27 (arguing that contract law diverges from morality in its failure to award punitive damages for intentional breaches).

191. The promise principle morality theory mandates expectation-based damages because if the promisor fails to fulfill his promise, it is fair that he should have to pay the equivalent of the promised performance. FRIED, supra note 137, at 17. The damages are based on the promisor's actions, but the damages also coincide with the purpose of compensatory damages for breach of contract, which is to compensate the nonbreaching party by placing him in the same position as if the promisor had performed. See supra Part II.A. In tort, benefit-of-the-bargain damages do not coincide with the purpose of compensatory damages, which is to restore the injured party to the position he was in before the tort occurred. See supra Part II.B. Moreover, punitive damagesavailable in tort but not for breach of contract - are the only type of tort damages capable of being based on the wrongdoer's conduct. See infra notes 222-23 and accompanying text. Thus, even if the promise principle would support an award of compensatory damages for breach of contract, it would also support an award of punitive damages for fraudulent misrepresentation. This is similar to how the same conduct can be the basis for both a breach-of-contract and tort action even though punitive damages are available only for the tort action. See infra note 263 and accompanying text. 
fraudulent misrepresentation cases do not involve promissory representations. In the contract context, if a party fails to perform as he promised, "it is fair that [he] should be made to hand over the equivalent of the promised performance."192 But the typical fraudulent misrepresentation concerns only the value of a good. ${ }^{193}$ Must the defendant still deliver the monetary equivalent of a good conforming to the misrepresentation? Even though the misrepresentation was fraudulent, it does not seem fair to award compensatory damages encompassing delivery of a good if the misrepresentation did not include any promise to convey the same good.

In fraudulent misrepresentation, the wrong occurs not when the nonconforming good is delivered but when the misrepresentation is made. ${ }^{194}$ The fraudulent misrepresentation itself is harmful because it creates a false belief. ${ }^{195}$ The immorality of the misrepresentation, however, does not create a compensable loss based on the later receipt of a good not conforming to the misrepresentation. A compensable loss exists only if the plaintiff incurred some actual loss in reliance on the misrepresentation, mainly out-of-pocket losses based on any difference between the purchase price and fair market value of the good.

\section{VII.THE RESUlting Problem Is MORE THAN MERE \\ OVERCOMPENSATION}

Perhaps benefit-of-the-bargain damages are not compensatory and cannot be justified as compensatory damages by any contract law theory. But is it really problematic to base compensatory damages on the lost expected benefit of the bargain? The obvious consequence is overcompensation, something that most plaintiffs would not mind.

Overcompensation is not tolerated in other torts. To the contrary, compensatory damages make the plaintiff whole and do no more. ${ }^{196}$ If the plaintiff incurs medical expenses, the amount of damages is based on the amount of those medical expenses. ${ }^{197}$ The factfinder lacks the ability

192. FRIED, supra note 137 , at 17.

193. See supra note 2.

194. See FRIED, supra note 137, at 9 (explaining that in a promise, "the wrong is done later, when the promise is not kept-while a lie is a wrong committed at the time of its utterance").

195. Id. at 78 ("A simple lie does harm because it is believed...."). A fraudulent misrepresentation regarding the value of a good creates only a belief regarding the value of the good; it does not create a belief regarding receipt of the good or any profit to be obtained through purchasing the good. See supra Part VI.A.

196. See supra Part II.B.

197. See 2 DoBBS, supra note $7, \S 8.1(3)$, at 375-76. 
to add additional compensatory damages onto the medical expenses simply because the factfinder is unhappy with the defendant's conduct. ${ }^{198}$ Similarly, the factfinder in a fraudulent misrepresentation claim should not be able to add additional compensatory damages simply because the defendant lied.

There is also a consequence greater than overcompensationmeasuring tort-based compensatory damages by the benefit of the bargain has enabled a disconnect between the plaintiff's loss and the amount of compensatory damages. Apparently, the plaintiff's loss no longer controls the amount of compensatory damages. The disconnect is evident in an exception that Massachusetts courts have developed to the majority benefit-of-the-bargain damages rule. Specifically, Massachusetts courts do not award benefit-of-the-bargain damages - the damages necessary to make the plaintiff whole-when the award is disproportionate to the defendant's conduct because the defendant gained no profit or because the plaintiff lacks actual losses. ${ }^{199}$

Suppose that the plaintiff agreed to purchase a good for $\$ 200$ after the defendant represented that it was worth $\$ 500$, but the delivered good was actually worth only $\$ 200$. Under the majority rule, the plaintiff needs $\$ 300$ in damages to be made whole. ${ }^{200}$ But under the Massachusetts exception, no damages are necessary to compensate the plaintiff because the defendant made no profit. ${ }^{201}$ Also under the Massachusetts exception, if the plaintiff never acquired the good, no compensatory damages are necessary. ${ }^{202}$ In fact, under these circumstances, not only are compensatory damages unnecessary

\footnotetext{
198. See id.

199. See Twin Fires Inv., LLC v. Morgan Stanley Dean Witter \& Co., 837 N.E.2d 1121, 1135 36 (Mass. 2005) (refusing to award benefit-of-the-bargain damages because the plaintiff had no actual losses and the defendant experienced no gain due to the alleged fraud). Thus, Massachusetts courts will still award benefit-of-the-bargain damages if the defendant made a profit. But see supra note 119 (explaining that the proper remedy to obtain the defendant's profits is restitution).

200. See supra Part III.D-E. Despite the plaintiff's lack of out-of-pocket losses, the Second Restatement directs that damages are appropriate. One of the Second Restatement's examples of when benefit-of-the-bargain damages are appropriate is if the good received by the plaintiff is something that "because of the matter misrepresented, he does not want and cannot use." RESTATEMENT (SECOND) OF TORTS $§ 549 \mathrm{cmts} . \mathrm{g} \& \mathrm{j}$ (1977). If the fair market value of the good equals the purchase price, the plaintiff has no out-of-pocket losses but has a good that he did not want. The Restatement claims that the only way to restore the plaintiff to his original position is to award benefit-of-the-bargain damages. Id. $\S 549 \mathrm{cmt}$. i. But this is not necessarily true. The plaintiff is obviously free to resell the good. See id. $\S 549 \mathrm{cmt}$. j. Any damages based on the delay or other consequences of being forced to resell could be recovered by the plaintiff as consequential damages. Reselling the good would be a hassle, but the buyer still needs to repurchase the good even after an award of benefit-of-the-bargain damages.

201. See Twin Fires Inv., LLC, 837 N.E.2d at 1136.

202. Id.
} 
according to Massachusetts law, they are also inappropriate because they would confer a "windfall." 203

The plaintiff"s situation no longer controls the amount of compensatory damages. The plaintiff acts no differently regardless of whether the defendant makes a profit or ultimately delivers the good. The plaintiff may lack out-of-pocket losses but still has disappointed expectations that, under the majority rule, must be compensated or the plaintiff will not be made whole. But, again, the plaintiff's situation does not control. Instead, the defendant's conduct - not profiting from the transaction, not delivering the good, or both-controls the amount of damages necessary to make the plaintiff whole.

The disconnect between the plaintiff's loss and the amount of compensatory damages draws the focus away from compensating the plaintiff. The amount of damages depends on factors that have nothing to do with the plaintiff and the plaintiff's resulting losses-factors like the defendant's conduct. When courts first began awarding benefit-ofthe-bargain damages for fraudulent misrepresentation, dissenters criticized that the benefit-of-the-bargain measure "places cause before effect" by awarding damages based on the defendant's conduct, the tort, instead of the plaintiff's resulting injury. ${ }^{204}$ It seems that courts now continue to focus on the "cause" of the damages but use the cause to reduce the plaintiff's damages.

If we allow this disconnect to continue within fraudulent misrepresentation, what is to stop it from permeating into other torts? The plaintiff's compensatory damages for personal injury apparently should differ depending on whether the defendant acted intentionally (in a battery claim) or negligently (in a negligence claim). This distinction already exists in misrepresentation, where lesser damages are available for negligent misrepresentation because "the fault of the maker of the misrepresentation is sufficiently less." 205 And further, the plaintiff's

203. Id. ("Where the plaintiffs have not lost the benefit of a bargain because of a misrepresentation and a defendant has not gained anything thereby, awarding benefit of the bargain damages would be more than is required 'reasonably [to] make the injured party whole'; it would create a "windfall." (quoting Kattar v. Demoulas, 739 N.E.2d 246, 258 (Mass. 2000))).

204. Hallen v. Martin, 167 N.W. 314, 323 (S.D. 1918) (Whiting \& Gates, JJ., dissenting).

205. RESTATEMENT (SECOND) OF TORTS $§ 552 \mathrm{cmt}$. a (1979). The difference in liability is due to the distinction between a duty of care and a duty of honesty. Id. The duty of honesty is implicit in every transaction, whereas the duty of care will exist only in certain circumstances. Id. Those certain circumstances include when the defendant has a pecuniary interest in the representation, which is presumed if the defendant gives the representation within his "business, profession, or employment." Id. $\S 549 \mathrm{cmt}$. d. By limiting the recognition of a duty of care to those representations, "the law promotes the important social policy of encouraging the flow of commercial information upon which the operation of the economy rests." Id. $\S 549 \mathrm{cmt}$. a. 
compensatory damages in negligence apparently should differ depending on whether the defendant was grossly negligent or merely negligent. ${ }^{206}$ Even without the possibility of permeation, how can benefit-of-thebargain damages be compensatory if the damages are based on factors other than the plaintiff's loss? And if benefit-of-the-bargain damages are compensatory even though their availability depends on factors other than the plaintiff's loss, what exactly does compensatory mean anymore?

Tort law cannot tolerate any disconnect between the amount of compensatory damages and the plaintiff's situation. The main purpose of tort law is to compensate the plaintiff, and the only way that tort law accomplishes this purpose is through awarding compensatory damages. ${ }^{207}$ If compensatory damages are not based on the plaintiff's loss, then compensatory damages may not make the plaintiff whole and tort law would not fulfill its main purpose. To ensure that compensatory damages continue to make the plaintiff whole, the only factor relevant to the measure of compensatory damages for fraudulent misrepresentation must be the plaintiff's actual, out-of-pocket losses.

\section{VIII.LIMITING THE RECOVERY OF BENEFIT-OF-THE-BARGAIN DAMAGES FOR FRAUDULENT MISREPRESENTATION}

The purposes of tort law control both the type of available damages and the measures of those damages. ${ }^{208}$ Consistent with the purposes of tort law, compensatory damages for fraudulent misrepresentation must be limited to out-of-pocket losses. The only purpose of tort law consistent with the awarding of benefit-of-the-bargain damages is to "punish wrongdoers and deter wrongful conduct." benefit-of-the-bargain damages are awarded for fraudulent misrepresentation, they can only be awarded as punitive damages.

\footnotetext{
206. See id. § $549 \mathrm{cmt}$. i.

207. Likely the only reason that the disconnect between the plaintiff's actual loss (supposedly measured by the lost benefit) and the amount of compensatory damages is tolerated is that benefitof-the-bargain damages are not really compensatory. See supra Part V. Surely, if a jury awarded compensatory damages based on the plaintiff's medical expenses, a court would not get away with reducing that verdict-awarding the plaintiff her medical expenses for one leg but not the otherbecause the defendant's conduct was not especially reprehensible.

208. RESTATEMENT (SECOND) OF TORTS $\S 901 \mathrm{cmt}$. a ("Only those damages will be awarded that tend to carry out one or more of these purposes [of tort law].").

209. Id. §901(c).
} 


\section{A. Limit Compensatory Damages to Out-of-Pocket Losses}

Tort-based compensatory damages are limited to the amount necessary to put the injured plaintiff in the same position as if the fraudulent misrepresentation had not occurred. ${ }^{210}$ Awarding the plaintiff out-of-pocket losses and any consequential damages fulfills this first purpose of tort law. Therefore, courts should limit recoverable compensatory damages for fraudulent misrepresentation to actual, out-ofpocket losses.

If the plaintiff lacks out-of-pocket losses or other consequential damages, the plaintiff has no claim because nominal damages are not available. " ${ }^{211}$ "[T]here can be no recovery [for fraudulent misrepresentation] if the plaintiff is none the worse off for the misrepresentation, however flagrant it may have been . . .."212

\section{B. Allow Recovery of Benefit-of-the-Bargain Damages Only as Punitive Damages}

Another purpose of tort law is to punish wrongdoers and deter wrongful conduct. ${ }^{213}$ Tort law accomplishes these purposes by awarding punitive damages. ${ }^{214}$ The purpose of benefit-of-the-bargain damages is to punish the fraudulent party - these damages should be awarded only as punitive damages. ${ }^{215}$

210. See id. $\S 901 \mathrm{cmt}$. a.

211. See KeETON ET AL., supra note $68, \S 110$, at $765-66$ (explaining that the modern claim for misrepresentation is "a descendant of the older action on the case" meaning "that the plaintiff must have suffered substantial damage before the cause of action can arise"); Derry v. Peek, [1889] 14 A.C. 337 (H.L.) 343 (appeal taken from Eng.) ("[F]raud without damage or damage without fraud does not give rise to such actions."). If the plaintiff has no actual damages, the claim fails; the court cannot create damages when none exist by awarding benefit-of-the-bargain damages. But see Murray v. Jennings, 42 Conn. 9, 9 (1875) ("In one sense the plaintiff would seem to have suffered no damage, but the law gives her the benefit of the contract ....").

212. KEETON ET AL., supra note $68, \S 110$, at 765 (explaining that nominal damages are not recoverable for fraudulent misrepresentation).

213. RESTATEMENT (SECOND) OF TORTS § 901(c).

214. See supra notes $26-29$ and accompanying text.

215. Some states do not allow an award of punitive damages unless the plaintiff recovers an award of underlying damages; some allow those underlying damages to be either nominal or compensatory, but some states require the underlying damages to be compensatory. See 1 DobBS, supra note 7, §3.11(10), at 513-14. Practically, benefit-of-the-bargain punitive damages may not be available if the plaintiff lacks out-of-pocket losses or consequential damages. The underlying compensatory damage requirement makes no sense in a case like fraudulent misrepresentation, where out-of-pocket losses may not exist, but the wrong is clear. The Supreme Court has implicitly recognized this by mentioning that a higher ratio between compensatory and punitive damages may be appropriate if compensatory damages are minimal; still though, this seems to imply that some compensatory damages are necessary for a punitive damage award to be constitutional. See infra 


\section{The Purpose of Benefit-of-the-Bargain Damages Is to Punish}

An early rationale for the availability of benefit-of-the-bargain damages for fraudulent misrepresentation was that the defendant cannot be better off damages-wise if he commits fraud as opposed to breach of contract. "[A] fraud accompanied by a broken promise should cost the wrongdoer as much as the breach of promise alone." 216 As explained by McCormick:

[I]f the defendant by willful falsehood has cozened the plaintiff into risking his property upon a bargain, which, upon the information given by the defendant, would have been profitable, a remedy which merely seeks to place the plaintiff back in the position he was in before seems hardly adequate. The plaintiff might as well be given the value of the expected bargain. ${ }^{2}$

The Second Restatement of Torts adopted this sentiment when concluding that out-of-pocket losses may not provide "just" compensation because, if the plaintiff does not have any out-of-pocket losses, the defendant could get away with fraud without civil punishment. $^{218}$

There is nothing wrong with the desire to punish the wrongdoer by making him pay as much in damages for fraud as he would have to pay for breach of contract. ${ }^{219}$ The way to punish the wrongdoer, however, is not to pretend that benefit-of-the-bargain damages are compensatory. ${ }^{220}$

notes 245-48 and accompanying text. Regardless, the solution to the problem - the lack of other underlying damages - is not to invent additional compensatory damages based on the lost expectation. Instead, courts should not require underlying compensatory damages or award nominal damages for fraudulent misrepresentation.

216. KEETON ET AL., supra note $68, \S 110$, at 769. It is also not clear why it is important for the amount of compensatory damages for contract and fraud to match. Assuming the plaintiff can bring and succeed on both claims, the damage awards will merge. See, e.g., Trimble v. Pracna, 167 S.W.3d 706, 711 (Mo. 2005) (explaining that when the plaintiff sought benefit-of-the-bargain damages for both fraud and contract claims, the damage awards merged because "[a] plaintiff is only entitled to be made whole once ... and the election of theories doctrines are intended to prevent a plaintiff from recovering more than one full recovery for the same harm").

217. MCCORMICK, supra note $128, \S 121$, at 453 (emphasis added).

218. See supra notes $66-68$ and accompanying text.

219. In tort, nominal damages are the proper remedy to vindicate legal rights despite the lack of actual damages. See RestATEMENT (SECOND) OF TORTS $\S 901$ cmt. b (1979). Nominal damages, however, are not available for misrepresentation. KEETON ET AL., supra note 68, § 110, at 765-66.

220. Hallen v. Martin, 167 N.W. 314, 322 (S.D. 1918) (Whiting \& Gates, JJ., dissenting) (explaining the concern that limiting damages to out-of-pocket losses for fraudulent misrepresentation might encourage or reward the wrongdoer and "might be good ground for holding that, in a proper case, punitive damages should be allowed"). For a discussion that benefit-of-thebargain damages cannot be compensatory as defined by tort law, see supra Part V.A. 
When awarded for fraudulent misrepresentation, benefit-of-thebargain damages are classic punitive damages. The point of benefit-ofthe-bargain damages is to punish the wrongdoer, and, in tort law, damages designed to punish or deter are punitive. ${ }^{221}$ Further, the current availability of benefit-of-the-bargain damages for misrepresentation depends not on the plaintiff's injury but on the defendant's culpability. ${ }^{222}$ Damages based "on behavior and characteristics of the defendant rather than the plaintiff" are punitive. ${ }^{223}$

Refreshingly, some courts are not afraid to admit this punitive purpose, commenting specifically that the "benefit-of-the-bargain rule is a punitive measure which 'compels [a] party guilty of fraud to make good his or her representations.",224 Even when courts cannot admit that benefit-of-the-bargain damages are punitive, they are still hesitant to award them when it would be unjust to punish the defendant. ${ }^{225}$ Courts recognize the punitive nature of benefit-of-the-bargain damages; they should, therefore, award benefit-of-the-bargain damages as punitive damages for fraudulent misrepresentation.

\section{The Plaintiff's Additional Burden to Demonstrate Entitlement to Punitive Damages}

Unlike compensatory damages, punitive damages are not automatically recoverable in tort, and their availability depends on state law. Some states do not allow recovery of punitive damages at all. ${ }^{226}$ Some states have statutorily defined the availability of punitive

221. See supra Part II.B.

222. See supra Part III.E-F (explaining that benefit-of-the-bargain damages are available when the defendant acts with an intent to deceive in making the misrepresentation but not if the defendant was negligent as to the representation's falsity).

223. Victor E. Schwartz et al., Prosser, Wade and Schwartz's Torts 520 (11th ed. 2005).

224. Goodrich \& Pennington Mortg. Fund, Inc. v. J.R. Woolard, Inc., 101 P.3d 792, 796 (Nev. 2004) (citing Lightning Litho, Inc. v. Danka Indus., 776 N.E.2d 1238, 1242 (Ind. Ct. App. 2002)).

225. See, e.g., Twin Fires Inv., LLC v. Morgan Stanley Dean Witter \& Co., 837 N.E.2d 1121, 1134-36 (Mass. 2005) (affirming lower court's decision to deny benefit-of-the-bargain damages of $\$ 13$ million and instead award approximately $\$ 40,000$ in reliance damages because the plaintiff had no actual losses and the defendant experienced no gain due to the alleged fraud); see also Barry Ravech, Conditions Precedent, Benefit of the Bargain Damages in Fraud and Proportionate Counsel Fees in Mass. Gen. Laws ch. 93A, § 11 Proceedings, 90 MASs. L. ReV. 28, 32 (2006) (discussing the Twin Fires court's refusal to award benefit-of-the-bargain damages because it "did not see fit to further punish the defendants by applying the more generous benefit of the bargain damage rule").

226. See MCCORMicK, supra note 128, §78, at 279 (discussing that Louisiana, Massachusetts, Nebraska, and Washington do not allow recovery of punitive damages, except if allowed by specific statute). 
damages. $^{227}$ Other states use a more general common law standard, allowing punitive damages if the defendant's conduct "is outrageous, because of the defendant's evil motive or his reckless indifference to the rights of others. $" 228$

In some jurisdictions, the finding that the defendant committed fraud alone is likely sufficient to give the jury the option to award punitive damages. ${ }^{229}$ "An intent to deceive is roughly equivalent to the requirement of an evil mind for punitive damages purposes."230 Thus, "actual fraud is often, though not always, sufficient to support the recovery of punitive damages." ${ }^{231}$ Some states even define by statute that punitive damages are appropriate if the plaintiff proves that the defendant committed "fraud," meaning the defendant made an "intentional misrepresentation ... with the intention of causing injury to the plaintiff." 232

227. These states include, but are not limited to, Alabama, California, Kentucky, and Nevada. See Ala. Code § 6-11-20 (2005); Cal. Civ. Code § 3294 (West 1997); Ky. ReV. Stat. AnN. $\S 411.186$ (West 2006); NeV. REV. STAT. ANN. § 42.005 (West 2000).

228. RESTATEMENT (SECOND) OF TORTS § 908(2) (1979); see also 1 DOBBS, supra note 7, $\S 3.11(2)$, at 468 (discussing that courts allow the recovery of punitive damages "if [the defendant] is malicious ... reckless ... oppressive, evil, wicked, guilty of wanton or morally culpable conduct, or shows flagrant indifference to the safety of others").

229. See MCCORMICK, supra note 128, § 121, at 453-54 (discussing that a "willful fraud," if proven, is likely sufficient to demonstrate entitlement to punitive damages).

230. Rowe v. Bankers Life and Cas. Co., No. CV-07-1281-PHX-MHM, 2008 WL 5156077, at *9 (D. Ariz. Dec. 9, 2008).

231. Id. (citing Farr v. Occidental Life Ins. Co., 699 P.2d 376, 383 (Ariz. Ct. App. 1984)); see also Whitworth v. Fid. Mortg. Co., No. C 05-04725 MHP, 2009 WL 1246687, at *6 (N.D. Cal. May 5 , 2009) (awarding punitive damages for fraudulent misrepresentation where the plaintiff established by clear and convincing evidence that the defendant "never intended to make good on his promises to the plaintiff"); Palmer v. Web Indus., No. CV 04-2362-PCT-SMM, 2007 WL 45927, at *8 (D. Ariz. Jan. 8, 2007) (awarding punitive damages for fraudulent misrepresentation because "[f]raud and misrepresentation are not acceptable business practices, and the conscious evil of such behavior is obvious"); Applied Capital, Inc. v. Gibson, No. Civ 05-98 JB/ACT, 2007 WL 5685131, at *14 (D.N.M. Sept. 27, 2007) ("Punitive damages are an appropriate sanction for fraudulent misrepresentation.”); Deep Marine Tech., Inc. v. Conmaco/Rector, L.P., 515 F. Supp. 2d 760, 772 (S.D. Tex. 2007) ("Texas law protects this interest by authorizing exemplary damages for fraudulent misrepresentation, including punitive damages that are designed 'to punish a party for its outrageous, malicious, or otherwise morally culpable conduct and to deter it and others from committing the same or similar acts in the future." (quoting Owens-Corning Fiberglas Corp. v. Malone, 972 S.W.2d 35, 40 (Tex. 1998))); In re Estate of Stockdale, Nos. Mon-P-234-03 \& Mon-P211-00, 2006 WL 3770841, at *14 (N.J. Super. Ct. App. Div. Dec. 26, 2006) ("Fraudulent misrepresentations are a sufficient basis for punitive damages."); Smith v. Reinhart Ford, 68 Pa. D. \& C.4th 432, 440 (Pa. Com. Pl. 2004) (acknowledging that "fraud and misrepresentation claims support punitive damages").

232. Ky. Rev. Stat. Ann. § 411.184. Alabama's, California's, and Nevada's punitive damage statutes contain similar language. See Ala. Code § 6-11-20; CAL. Civ. Code $§ 3294$; Nev. Rev. STAT. ANN. § 42.001 . 
Not all states are so quick to award punitive damages for fraudulent misrepresentation. "Fraudulent, intentional, malicious, or reckless conduct which warrants an award of compensatory damages does not necessarily qualify for an award of punitive damages."233 Simply because the defendant intended to deceive does not mean his conduct is so egregious that it justifies an award of punitive damages. ${ }^{234}$ State courts adopting this sentiment hold that punitive damages should be awarded in only the most egregious cases. ${ }^{235}$ And even in those states that allow the recovery of punitive damages based on fraud alone, the plaintiff likely has to prove fraud by clear and convincing evidence. ${ }^{236}$

Awarding benefit-of-the-bargain damages only as punitive damages will make it more difficult for the plaintiff to recover them. But even as compensatory damages, benefit-of-the-bargain damages are not always available for fraudulent misrepresentation. As already discussed, Massachusetts law limits the recovery of benefit-of-the-bargain damages "to cases of intentional misrepresentation where... [the plaintiff] has actually acquired something in a transaction that is of less value than he was led to believe it was worth when he bargained for it." 237

Moreover, it is appropriate that benefit-of-the-bargain damages should not always be available for fraudulent misrepresentation. It is clear that benefit-of-the-bargain damages are something more than compensatory; the damages make the plaintiff better off than before the tort. $^{238}$ A plaintiff thus should have an additional burden to demonstrate

233. Jarmakowicz v. Suddarth, No. M1998-00920-COA-R3-CV, 2001 WL 196982, at*13 (Tenn. Ct. App. Feb. 28, 2001).

234. See, e.g., Orlando v. Novurania of Am., Inc., 162 F. Supp. 2d 220, 226 (S.D.N.Y. 2001) (finding that the "defendant's misrepresentation about the hull not being repaired is neither evil nor reprehensible as that term is understood in the context of punitive damage awards"); Greenell Corp. v. Penobscot Air Serv., Ltd., No. 99-31-P-C, 1999 WL 33117116, at*10 (D. Me. Aug. 19, 1999) (noting that evidence of misrepresentations and that the defendant led the plaintiff along are "insufficient for the necessary level of outrageous conduct"); Reed Cadillac-Olds, Inc. v. Habhab, No. 98-0916, 2000 WL 1157819, at *4 (Iowa Ct. App. Aug. 16, 2000) ("Punitive damages are generally not allowed in fraudulent misrepresentation or breach of contract cases absen[t] a showing of malice, fraud, or other illegal acts.").

235. Jarmakowicz, $2001 \mathrm{WL} 196982$, at *13 (concluding that if punitive damages are awarded in cases where the defendant's conduct was less than "the most egregious," punitive damages would lose their deterrent effect); see also Johnson v. Black Bros., 879 So. 2d 525, 529 (Miss. Ct. App. 2004) ("[P] unitive damages are appropriate only in extreme cases and should be allowed "only with caution and within narrow limits." (quoting Beta Beta Chapter of Beta Theta Pi Fraternity v. May, 611 So. 2d 889, 894 (Miss. 1992))).

236. 1 DoBBS, supra note $7, \S 3.11(4)$, at $484-85$ (explaining that many jurisdictions have rejected the "preponderance of the evidence" standard and are increasingly requiring a "clear and convincing evidence" standard or higher).

237. Twin Fires Inv., Inc. v. Morgan Stanley Dean Witter \& Co., 837 N.E.2d 1121, 1135 (Mass. 2005)

238. See supra Part V.A. 
entitlement to this financial windfall. If benefit-of-the-bargain damages are awarded only as punitive damages, that appropriate, additional burden would require the plaintiff to prove by clear and convincing evidence that the defendant's conduct was so outrageous as to justify an award of punitive damages.

3. Awarding the Plaintiff Lost Expectations Increases Predictability in Punitive Damage Awards

"Whether to award punitive damages and the determination of the amount are within the sound discretion of the trier of fact...."239 In making this determination, the factfinder looks to the defendant's act, the defendant's motive, the extent of harm to the injured person, the burden put on the plaintiff due to the injury, the defendant's wealth, and whether others have been affected by or brought similar claims against the defendant based on his conduct at issue. ${ }^{240}$ Using these general factors, factfinders award punitive damages more frequently and in higher amounts in the United States than anywhere else in the world. ${ }^{241}$

According to the United States Supreme Court, the problem is not that punitive damage awards are frequent and high but that the amounts of the awards are "stark[ly] unpredictab[le]." 242 Also according to the Supreme Court, this unpredictability will remain as long as courts continue to use general jury instructions: "Instructions can go just so far in promoting systemic consistency when awards are not tied to specifically proven items of damage ...."243

Tying the amount of punitive damages to the plaintiff's expectation would provide some consistency in punitive damage awards for fraudulent misrepresentation. The court could instruct the jury to consider the general factors relevant to the amount of punitive damages and also to consider specifically the defendant's misrepresentation of the value and the value of the good with which the plaintiff is left. Even without an aim to improve consistency, "[b]etter guidance in instructions

239. ReSTATEMENT (SECOND) OF TORTS $\S 908 \mathrm{cmt} . \mathrm{d}(1979)$.

240. Id. $\S 908 \mathrm{cmt}$. e. The Supreme Court recently clarified that when a jury is determining an amount of punitive damages, it cannot increase the damages to punish the defendant for its conduct towards others besides the plaintiff. Philip Morris USA v. Williams, 549 U.S. 346, 354 (2007). The jury may, however, consider the defendant's conduct towards others when determining the reprehensibility of the defendant's conduct toward the plaintiff and use that reprehensibility to determine the amount of punitive damages. Id. at 355.

241. Exxon Shipping Co. v. Baker, 128 S. Ct. 2605, 2623 (2008).

242. Id. at 2625 .

243. Id. at 2628. 
is a good idea."244 Jury instructions specifically indicating that the jury should consider the plaintiff's lost benefit would provide the jury with a connection between the defendant's conduct and the amount of punitive damages.

Unfortunately, increasing the predictability in the amounts of punitive damages for fraudulent misrepresentation may not necessarily mean that the awards would be constitutional. Allegedly excessive punitive damage awards have been the subject of multiple due process constitutional challenges. ${ }^{245}$ Most of these challenges occurred when the punitive award greatly exceeded the compensatory award. This is also likely to occur in fraudulent misrepresentation claims if benefit-of-thebargain-based compensatory damages are not awarded because out-ofpocket losses are often minimal. At the same time, an award of punitive damages may be high because the defendant clearly committed a wrong.

So far, the Supreme Court has refused to define a constitutionally acceptable ratio between the amounts of punitive and actual damages awarded. $^{246}$ But the Court has suggested that a higher ratio may be appropriate if the actual injury is minimal but the wrong is clear. ${ }^{247}$ Thus, even if the benefit-of-the-bargain-based punitive damage award

244. 1 DoBBS, supra note $7, \S 3.11(11)$, at 520 .

245. See, e.g., BMW of N. Am., Inc. v. Gore, 517 U.S. 559, 560 (1996) (involving $\$ 4000$ in compensatory damages and $\$ 4$ million in punitive damages); State Farm Mut. Auto. Ins. Co. v. Campbell, 538 U.S. 408, 409 (2003) (involving \$1 million in compensatory damages and \$145 million in punitive damages); Williams, 549 U.S. at 350 (involving $\$ 821,000$ in compensatory damages and $\$ 79.5$ million in punitive damages).

246. The Supreme Court offered the following explanation for its resistance to defining set ratios for the relationship between compensatory and punitive damages:

[W] have been reluctant to identify concrete constitutional limits on the ratio between harm, or potential harm, to the plaintiff and the punitive damages award. We decline again to impose a bright-line ratio which a punitive damages award cannot exceed. Our jurisprudence and the principles it has now established demonstrate, however, that, in practice, few awards exceeding a single-digit ratio between punitive and compensatory damages, to a significant degree, will satisfy due process. ... While these ratios are not binding, they are instructive. They demonstrate what should be obvious: Single-digit multipliers are more likely to comport with due process, while still achieving the State's goals of deterrence and retribution, than awards with ratios in range of 500 to 1 , or, in this case, of 145 to 1 .

Nonetheless, because there are no rigid benchmarks that a punitive damages award may not surpass, ratios greater than those we have previously upheld may comport with due process where "a particularly egregious act has resulted in only a small amount of economic damages." The converse is also true, however. When compensatory damages are substantial, then a lesser ratio, perhaps only equal to compensatory damages, can reach the outermost limit of the due process guarantee.

Campbell, 538 U.S. at 424-25 (internal citations omitted).

247. Gore, 517 U.S. at 582 ("Indeed, low awards of compensatory damages may properly support a higher ratio than high compensatory awards, if, for example, a particularly egregious act has resulted in only a small amount of economic damages."). 
greatly exceeds the amount of compensatory losses, this higher ratio may not be constitutionally offensive. Also, a benefit-of-the-bargain-based punitive damage award should cause less constitutional problems because it is specifically related to the facts of the case. ${ }^{248}$

\section{Awarding Benefit-of-the-Bargain Damages as Punitive Damages Will Reaffirm the Distinction Between Contract and Tort Compensatory Damages}

If benefit-of-the-bargain damages are available only as punitive damages for fraudulent misrepresentation, courts will be better able to distinguish between contract and tort actions. In most cases, the available compensatory damages will no longer be identical for breach of contract and fraudulent misrepresentation. Similarly, tort compensatory damages will appropriately mirror breach-of-contract, reliance-based compensatory damages.

1. Classifying Benefit-of-the-Bargain Damages as Punitive in Tort Enables Courts to Distinguish Between Contract and Tort Actions Based on the Damages Sought

The current most popular effort to distinguish contract and tort actions is the economic-loss doctrine. ${ }^{249}$ The doctrine's prohibition of the recovery of economic losses in tort, however, goes too far. If courts do not develop exceptions, fraudulent and negligent misrepresentation claims will not survive. ${ }^{250}$ Also, the economic-loss doctrine is inconsistent with tort law's traditional governance of damages the plaintiff incurs in reliance on a representation. ${ }^{251}$

A better analysis for courts to use to distinguish between contract and tort is to focus on the nature and cause of the damages sought. If the plaintiff seeks benefit-of-the-bargain damages, the plaintiff's claim is for breach of contract. Traditionally, only contract law compensates the plaintiff for disappointed expectations. ${ }^{252}$ More importantly, the breach of the contract is the cause of those disappointed expectations and

\footnotetext{
248. See Campbell, 538 U.S. at 425 (noting that the appropriateness of a punitive damage amount depends on the "facts and circumstances of the defendant's conduct and the harm to the plaintiff').

249. See supra notes 93-98 and accompanying text.

250. See supra note 99 and accompanying text.

251. See supra note 89 and accompanying text.

252. See supra Part II.A.1.
} 
damages based on that disappointment should be recoverable as compensatory damages in contract law. ${ }^{253}$

If the plaintiff seeks out-of-pocket losses or consequential damages incurred in reliance on the representation, the plaintiff's claim is for misrepresentation, a tort. These are traditional tort damages and should continue to be governed by tort law. If the defendant's conduct is egregious, the plaintiff can also seek punitive damages, another traditional tort remedy.

Differentiating contract and tort actions based on the claimed damages has advantages over the economic-loss doctrine. Similar to the economic-loss doctrine, this analysis requires a plaintiff to seek relief for breach of contract to recover damages based on expected economic gains-benefit-of-the-bargain damages. At the same time, this analysis still allows recovery of compensatory damages, including economic losses incurred due to the plaintiff's reliance on a misrepresentation in tort.

\section{Compensatory Damages in Tort Should Mirror Reliance-Based}

Compensatory Damages in Contract

Although breach-of-contract and tort actions are different causes of action, there are some similarities between the types of compensatory damages available for both. Limiting compensatory damages for fraudulent misrepresentation ensures proper consistency between tort damages and reliance-based compensatory damages for breach of contract.

Scholars and courts agree that "tort damages are analogous to reliance damages, which are awarded in contract when there is particular difficulty in measuring the expectation interest." 254 This is because "tort damages generally compensate the plaintiff for loss and return him to the position he occupied before the injury." ${ }^{255}$ Similarly, reliance-based compensatory damages in contract seek to put the plaintiff in the position as if the parties never entered into the contract. ${ }^{256}$ The aim of both types of compensatory damages is to return the plaintiff to the status quo, before the tort occurred or the contract was made. Tort compensatory

\footnotetext{
253. See supra Part VI.A.

254. E. River S.S. Corp. v. Transamerica Delaval, Inc., 476 U.S. 858, 873 n.9 (1986).

255. Id.

256. See supra Part II.A.2.
} 
damages for misrepresentation thus should mirror reliance-based compensatory damages for breach of contract.

The only tort-based damage similar to expectation-based compensatory damages for breach of contract is punitive damages. What these types of damages have in common is the financial windfall that both provide to the plaintiff. In contract, expectation-based compensatory damages require the breaching party to perform as the parties originally contemplated, thus giving the nonbreaching plaintiff something he lacked before the lawsuit. ${ }^{257}$ The only tort-based damages capable of providing the plaintiff with a windfall are punitive damages. ${ }^{258}$ By definition, tort-based compensatory damages do not provide the plaintiff with a financial windfall. ${ }^{259}$ Tort law tolerates a windfall to the plaintiff as a "means of securing public good through a kind of quasi-criminal punishment in the civil suit."260 Thus, even though they are both labeled "compensatory," benefit-of-the-bargainbased compensatory damages for breach of contract are actually more similar to punitive damages in tort than they are to compensatory damages in tort.

\section{The Availability of Benefit-of-the-Bargain Damages in Contract Does Not Preclude Their Limited Availability in Tort}

Some courts may balk at the idea of classifying benefit-of-thebargain damages as punitive because these same damages are available for breach of contract whereas punitive damages generally are not. ${ }^{261}$ The fact that benefit-of-the-bargain damages are regarded as compensatory in contract does not preclude courts from treating the same damages as punitive in tort. To the contrary, this differential treatment is

257. See supra note 158 and accompanying text (explaining that expectation-based compensatory damages are strange even in contract because the damages appear to do more than compensate).

258. See supra Part II.B.

259. See supra Part II.B.

260. 1 DoBBS, supra note 7, § 3.11(1), at 457; see also MCCORMICK, supra note $128, \S 84$, at 296 (explaining that "the recovery of punitive damages is a windfall and not a right").

261. RESTATEMENT (SECOND) OF CONTRACTS § 355 (1981) ("Punitive damages are not recoverable for a breach of contract unless the conduct constituting the breach is also a tort for which punitive damages are recoverable."). Punitive damages are prohibited partially because contract law recognizes the idea of an efficient breach - when a breaching party chooses to breach because the breach would be more economically efficient than performance. See Shmuel I. Becher, A "Fair Contracts" Approval Mechanism: Reconciling Consumer Contracts and Conventional Contract Law, 42 U. MiCH. J.L. REFORM 747, 779 (2009) (explaining that the award of punitive damages would undermine the basic principle of efficient breach because "performance will occur even where breach would be more efficient, ex post, punitive damages result in inefficient performances"). 
proper based on the differing purposes of compensatory damages in contract and tort. ${ }^{262}$ Moreover, the fact that the defendant may have also committed a breach of contract does not preclude an award of punitive damages if he also commits an intentional tort. ${ }^{263}$ Thus, treating benefitof-the-bargain damages as punitive in tort law is actually consistent with the award of benefit-of-the-bargain damages in contract law.

\section{CONCLUSION}

Compensatory damages in tort are only supposed to be those damages necessary to return the plaintiff to the same position he would have been in had the tort not occurred. The majority of jurisdictions hold that a plaintiff needs compensation for a lost expectation-benefit-ofthe-bargain damages - to be made whole after relying on a fraudulent misrepresentation. Of course, those same jurisdictions may award less in damages and make the plaintiff less than whole if the defendant did not profit from the fraudulent misrepresentation or if the plaintiff did not receive a good from the defendant. Apparently, it's okay to make the plaintiff less than whole in these factual variations even though the plaintiff still lost an expectation. Similarly, the majority of jurisdictions - the same jurisdictions that believe a plaintiff needs benefit-of-the-bargain damages to be made whole after a fraudulent misrepresentation-hold that benefit-of-the-bargain damages are not necessary to compensate a plaintiff for a lost expectation if the defendant merely acted negligently. Again, apparently it's okay to award less in damages despite the exact same injury because the defendant was merely negligent.

Applying the fraudulent misrepresentation conception of compensatory to other torts, the amount of damages available to a plaintiff for injuries sustained in a car accident would depend on whether the defendant acted intentionally or negligently. It would be permissible to give the plaintiff damages for medical expenses related to one leg, but not the other, if the defendant acted intentionally but his conduct was still not especially reprehensible. Or it would be okay to not compensate the plaintiff for damages related to a preexisting medical condition if the defendant was merely negligent instead of grossly negligent.

262. See supra Part II.

263. RESTATEMENT (SECOND) OF TORTS § $908 \mathrm{cmt}$. b (1979) ("When, however, the plaintiff has a right in the alternative to sue for a breach of contract or for a tort, the fact that his act or omission amounts to a breach of contract does not preclude the award of punitive damages if the action is brought for the tort and the tort is one for which punitive damages are proper."). 
The main purpose of tort law is to compensate injured parties, and tort law does so through compensatory damages. But if factors other than the plaintiff's situation control the amount of compensatory damages - factors like the defendant's intent-tort law no longer accomplishes its main purpose. Tort law cannot tolerate this possibility, either generally or within misrepresentation law.

It is time to stop pretending that benefit-of-the-bargain damages are compensatory damages in tort. Clearly, the damages put the plaintiff in a better position than before the tort by providing a financial windfall. Moreover, if the damages were truly compensatory, they would also be available for negligent misrepresentation. Even if benefit-of-the-bargain damages are compensatory in contract law, they are not compensatory in tort. Unlike a contract, a misrepresentation does not create an expectation; even if it did, expectations do not control the existence of tort duties and similarly should not control the amount of tort damages. Also, the various practical and theoretical justifications for awarding benefit-of-the-bargain damages in contract law-the expectation's present value, the promotion of efficient breaches and commercial activity, and the morality-based promise principle - do not apply to tort law.

The proper compensatory damages for fraudulent misrepresentation are the plaintiff's out-of-pocket losses. As for benefit-of-the-bargain damages, these damages still seem appropriate for fraudulent misrepresentation because the defendant may deserve to be punished. The desire to punish a defendant who commits fraud is not wrong - it is fraud, after all. But jurisdictions need not rewrite the meaning of compensatory in tort law to make the defendant pay for his wrongful act; tort law already awards punitive damages to punish and deter the defendant. Awarding benefit-of-the-bargain damages only as punitive damages ensures that courts award such damages only when the defendant deserves punishment and ensures that the punishment relates to the misrepresentation. More importantly, awarding benefit-of-thebargain damages as punitive damages restores the meaning of compensatory in tort law by reconnecting the plaintiff's injury with the amount of compensatory damages. 